\title{
Agronomic Biofortification with Se, Zn, and Fe: An Effective Strategy to Enhance Crop Nutritional Quality and Stress Defense-A Review
}

\author{
Justyna Szerement ${ }^{1} \oplus$ - Alicja Szatanik-Kloc ${ }^{2} \cdot$ Jakub Mokrzycki $^{1} \cdot$ Monika Mierzwa-Hersztek $^{1,3}$
}

Received: 23 August 2021 / Accepted: 28 November 2021 / Published online: 3 December 2021

(c) The Author(s) 2021

\begin{abstract}
Human micronutrient deficiencies are a widespread problem worldwide and mainly concern people whose diet (mainly of plant origin) consists of insufficient amounts of critical vitamins and minerals. Low levels of micronutrients in plants are linked to, i.e., their decreasing concentration in soils and/or low bioavailability and presence of abiotic stresses which disturb the proper growth and development of plants. Agronomic biofortification of crops is a very promising way to improve the concentration of micronutrients in edible parts of crops without compromising yield and is recognized as the cheapest strategy to alleviate hidden hunger worldwide. The review is focused on the factors influencing the effectiveness of biofortified crops (a type of application, form, and a dose of applied microelement, biofertilizers, and nanofertilizers). Also, the accumulation of zinc, selenium, and iron in edible parts of crops, their effects on metabolism, morphological and yield parameters, and an impact on plants' defense mechanisms against abiotic stress like salt, high/low temperature, heavy metal, and drought was discussed. Finally, the directions of future agronomic biofortification studies are proposed.
\end{abstract}

Keywords Agronomic biofortification $\cdot$ Biofertilizer $\cdot$ Iron $\cdot$ Nanofertilizer $\cdot$ Plant nutrition $\cdot$ Selenium $\cdot$ Zinc

\section{Introduction}

It is estimated that more than 2 billion people (one in three) globally suffer from micronutrient deficiencies, also known as a "hidden hunger" (Prom-u-thai et al. 2020). These deficiencies are usually prevalent in highly developed countries and are more common among growing and developing children, pregnant and lactating women, sportsmen, and manual labor workers. Among the micronutrients, those most associated with micronutrient malnutrition worldwide are zinc $(\mathrm{Zn})$, selenium (Se), and iron (Fe).

Justyna Szerement

jsze@agh.edu.pl; jszerement@gmail.com

1 Department of Mineralogy, Petrography and Geochemistry, Faculty of Geology, Geophysics and Environmental Protection, AGH University of Science and Technology, Mickiewicza 30, 30-059 Krakow, Poland

2 Department of Physical Chemistry of Porous Materials, Institute of Agrophysics, Polish Academy of Sciences, Doświadczalna 4, 20-290 Lublin, Poland

3 Department of Agricultural and Environmental Chemistry, University of Agriculture in Krakow, Mickiewicza 21, 31-120 Krakow, Poland
Researchers around the world continue their attempts to develop Se-, Zn-, and Fe-enriched food products to minimize their related deficiency disorders. Proper nutrition is key to good human health and according to the World of Human Organization (WHO), it mainly depends on sustainable agriculture (Athar et al. 2020). Unfortunately, current agricultural systems are still mostly oriented toward achieving high crop yields rather than nutritional quality, thus enhancing the concentrations of mineral micronutrients has become a key task in agriculture production. However, it is challenging to simultaneously increase the production of food enriched with essential micronutrients which does not cause obvious negative symptoms for plants like, i.e., limiting growth and productivity.

The reduced level of micronutrients in crops may be a consequence of different constraints like low levels or low bioavailability of essential elements in the soil (Manojlović et al. 2019), sub-optimal abiotic conditions including extremely high or low temperature, $\mathrm{pH}$, water deficit, or anaerobic conditions, and also the presence of other elements (micro and macroelements and heavy metals). It was estimated that about $50 \%$ of cereals cultivated soils are $\mathrm{Zn}$ deficient. The Fe deficiency mostly occurs in calcareous (Jalal et al. 2020). Micronutrient deficiencies are more 
common in humid temperate and tropical regions where the intense leaching associated with high precipitation is observed. Another cause is the use of plant species with a low ability to accumulate sufficient quantities of micronutrients in their edible parts.

Biofortification is one of the ways to provide an increased level of micronutrients in crops (Huang et al. 2020). It has been shown that biofortified crops increase micronutrient intake and have a significant positive effect on human health (Bouis and Saltzman 2017; Praharaj et al. 2021). There are three major approaches to biofortification: agronomic, conventional plant breeding, and plant breeding using genetic engineering (Garg et al. 2018). Among them, agronomic biofortification, which is aimed at supplying micronutrients that can be directly absorbed by the plant by application with mineral and/or foliar fertilizers andlor the improvement of the solubilization and mobilization of mineral elements in the soil, is recognized to be the simplest method used to enhance levels of microelements in crops. Agronomic biofortification is also recognized as one of the cheapest ways to reduce mineral deficiency in the human diet. Additionally, many reports evidence that biofortification, besides micronutrient enrichment of plants, also has a significant influence on the synthesis of other compounds that exhibit nutritional properties (Newman et al. 2021; Puccinelli et al. 2021b, 2019a; Skrypnik et al. 2019). For plants, application of $\mathrm{Zn}, \mathrm{Se}$, and Fe also effectively supports the fight with biotic stresses (Adrees et al. 2021; Noreen et al. 2020; Rizwan et al. 2019). The concentration range between the beneficial and toxic effects of $\mathrm{Zn}, \mathrm{Se}$, and Fe for crops is very narrow, thus a well-thought-out approach to choosing plant species for enrichment with microelements, strict selection concentrations and form in fertilizers, selection of appropriate type of fertilizer, and studies on the accumulation of these microelements by a specific species or even plant variety are necessary to obtain crops with high nutrition quality.

The paper covers the newest findings under agronomic biofortification with $\mathrm{Zn}, \mathrm{Se}$, and $\mathrm{Fe}$. The first part of the review is focused on the main factors that determine the effectiveness of micronutrient biofortification. The next section provides some examples of the use of fertilizers based on nanotechnology and supported by microorganisms. The following section describes the beneficial effect of biofortification on increasing microelement content in edible parts of plants and also synthesis many compounds show health benefits. The last part of the paper discusses the influence of $\mathrm{Zn}$, $\mathrm{Se}$, and Fe biofortification on the alleviation of symptoms of abiotic stresses. In the conclusion section, the directions of future agronomic biofortification studies are proposed. The most important findings and information about conditions/ type of experiments from collected research papers were presented in tables. Additionally, the enrichment factor (EF) was calculated. EF of the microelements was calculated as a ratio of results obtained from the most advantageous fertilization of the crops $\left(C_{\max }\right)$ in relation to the control group $\left(C_{\text {control }}\right)$, according to the formula:

$\mathrm{EF}=\frac{C_{\max }}{C_{\text {control }}}$

Estimation of EF was performed based on the data contained in the articles (in a numerical or graphical form).

\section{Factors Influencing the Effectiveness of Biofortification with Zn, Se, and Fe Edible Parts of Plants}

Many factors influencing the effectiveness of biofortification with $\mathrm{Zn}, \mathrm{Se}$, and $\mathrm{Fe}$, including plant species, genotypes, and phenotypes; soil characteristics; type of application; and dose/form of applied micronutrients and climatic conditions have been widely investigated in recent years (Ebrahimi et al.2019; El-ramady et al. 2021; Izydorczyk et al. 2021; Jones et al. 2017; Manojlović et al. 2019; Niyigaba et al. 2019; Ramzan et al. 2020; Smažíková et al. 2019; Sago et al. 2018). Most studies were performed under controlled conditions mainly on cereal, rice, grass, herbage, and corn (Ros et al. 2016). In this section, we discuss the types of applied fertilizers and the forms/doses of applied Zn, Fe, and Fe.

\subsection{Type of Application}

The application of micronutrients fertilizer to the soil is the most common practice and has been used for years; however, in addition to various limitations associated with soil properties, it should be mentioned that (i) applied fertilizers have a low recovery efficiency, (ii) this strategy requires regular application, and (iii) different granule size leads to uneven application of nutrients. Currently, much more attention is turned towards the application of foliar fertilization, where micronutrients are applied directly to plants leaves. It was found that the application of foliar Se fertilizer improved the durum wheat grain Se concentration twice in comparison with soil application at the same dose of Se (Galinha et al. 2014). On the other hand, $\mathrm{Zn}$ fertilization of wheat was the most effective for the application of combined soil and foliar fertilizers (GomezCoronado et al. 2016). In research on mungbean, the $\mathrm{Zn}$ grain concentration after application of $1.0 \%$ of solution of zinc sulfate was about 1.7 times higher (Haider et al. 2018a) than soil $\mathrm{Zn}$ application at a concentration of $10 \mathrm{mg} \mathrm{kg}^{-1}$ soil (Haider et al. 2018b). However, it is worth noting that successful foliar fertilization requires, i.e., higher leaf area for better adsorption of the applied micronutrient. Additionally, this type of fertilization can 
be limited by environmental conditions, particularly air temperature, wind speed and direction, rainfall, and relative humidity, and should be applied at the adequate stage of the growth and development of crops. For example, Wang et al. (2020b) suggested that the foliar application of Se in both forms (selenite or selenate) at the pre-filling stage has a greater effect on Se concentration in wheat grains in comparison to the application at the pre-flowering stage. Foliar spray of $\mathrm{Zn}$ and $\mathrm{Fe}$ was applied four times, one every 10 days in the flagging to grain filling stages in wheat (Jalal et al. 2020). Deng et al. (2017) proved that the concentration of Se in grains after application of both selenite and selenate at the full heading stage of rice was 2.9-3.5 times higher than at the late tillering stage. The best fertilizer effect for chickpea was obtained for application of zinc sulfate at sowing combined with foliar $\mathrm{Zn}$ application at flowering and pod formation stages (Pal et al. 2019).

Soilless cultivation represents a promising opportunity for the agricultural section, especially in the regions characterized by soil degradation and limited water availability. For this reason, currently, more research is aimed at the enrichment of crops with micronutrients are performed under hydroponic conditions (Giordano et al. 2019; Puccinelli et al. 2019a; da Silva et al. 2020). Hydroponic cultivation has several advantages including, i.e., monitoring of nutrient concentration which in turn allows ensuring an optimal nutrient acquisition by plants without leading to nutritional disorders (Sambo et al. 2019). Skrypnik et al. (2019) noted that the application of Se to the nutrient solution had a significant effect on the essential oil content in basil leaves compared to foliar application.

Some authors suggested that the combined application of $\mathrm{Zn}, \mathrm{Fe}$, and Se soil and foliar fertilizers (Gomez-Coronado et al. 2016; Rivera-Martin et al. 2020) and fertilization with amendments like, i.e., biochar or salicylic acid (Ramzani et al. 2016; Smoleń et al. 2019) influenced a better efficiency for microelements accumulation in crops compared to when used separately. For example, it was found that $\mathrm{Zn}$ fertilization improved Fe concentration in grains (Niyigaba et al. 2019). The addition of microelements is usually applied in combination with the appropriate macroelements fertilization (NPK). It is well-known that the plant's $\mathrm{N}$ status is an important factor influencing increased levels of $\mathrm{Zn}$ and $\mathrm{Fe}$ in vegetative tissue. A strong correlation between $\mathrm{Zn}$ and $\mathrm{Fe}$ grain concentration and urea application was found for wheat (Montoya et al. 2020) and chickpea (Pal et al. 2019). The foliar application of zinc sulfate in conjunction with urea significantly increased not only $\mathrm{Zn}$ uptake but also the total $\mathrm{N}$ uptake and the efficiency of urea $\mathrm{N}$ fertilization. Additionally, Gonzales et al. (2019) proved that application of $\mathrm{Zn}$ fertilizer allows for a possible reduction of $\mathrm{N}$ application while maintaining barley grain yield and nutrition quality.

The impact of combined fertilization and its effects on plants are presented in Table 1.

\subsection{Form and Dose of Applied Micronutrient}

Application of appropriate form and dose of micronutrients has a significant effect on the accumulation of micronutrients in crops. The increase of soil zinc sulfate application increased $\mathrm{Zn}$ grain accumulation in wheat in the field study (Liu et al. 2017); however, Liu et al. (2019) noted that the percentage of $\mathrm{Zn}$ translocated from root to shoot decreased with increasing $\mathrm{Zn}$ application. In the study conducted by Gomez-Coronado et al. (2016), all of the tested wheat varieties (INIAV-1-10, Ardia, Nabao, Roxo) fertilized by soil $\mathrm{Zn}$ (applied as a zinc sulfate) at the concentration of the $50 \mathrm{~kg} \mathrm{~h}^{-1}$ accumulated in grains about two times less $\mathrm{Zn}$ in comparison to results presented for wheat by Liu et al. (2019). Fertilization with Zn, which is usually applied as zinc sulfate, is the most commonly used fertilizer. The application of zinc sulfate not only improves the $\mathrm{Zn}$ concentration in edible parts of crops but also is the source of sulfur for crops (Persson et al. 2016). The presence of S-rich proteins is important for $\mathrm{Zn}$ storage in the endosperm and suggests a synergy of $\mathrm{Zn}$ accumulation due to $\mathrm{S}$ application. However, Montoya et al. (2020) suggested that the application of $\mathrm{Zn}$ in an organic form enhanced grain yield more than inorganic form (i.e., zinc sulfate), especially with recommended $\mathrm{N}$ rate. Márquez-Quiroz et al. (2015) indicated that application of complexes of Fe (Fe-EDDTA) is a more effective way to enhance the level of Fe in cowpea bean seed compared to an inorganic form. Se is usually applied as a selenate which is recognized as having more bioavailability for the plant than selenite (Li et al. 2018). It was found that at the same spraying stages, the grain Se concentration in rice was about two times higher for selenate than in selenite (Deng et al. 2017). However, there was no significant influence on grain yield and total biomass between the two forms of Se fertilizers. The soil fertilization with selenate caused the highest concentration of Se in radish in comparison to foliar fertilizer and selenite form application (da Silva et al. 2020). Contrary, Longchamp et al. (2015) noted that soil application of selenite could be attractive because selenite is less mobile than selenate and can enrich the soil in Se at each fertilization meaning that in the long term, plants grown on this soil will be enriched in selenium without the use of Se fertilizers.

An impact of the type of fertilization and trial, form, and doses of applied microelements is summarized in Table 2. 


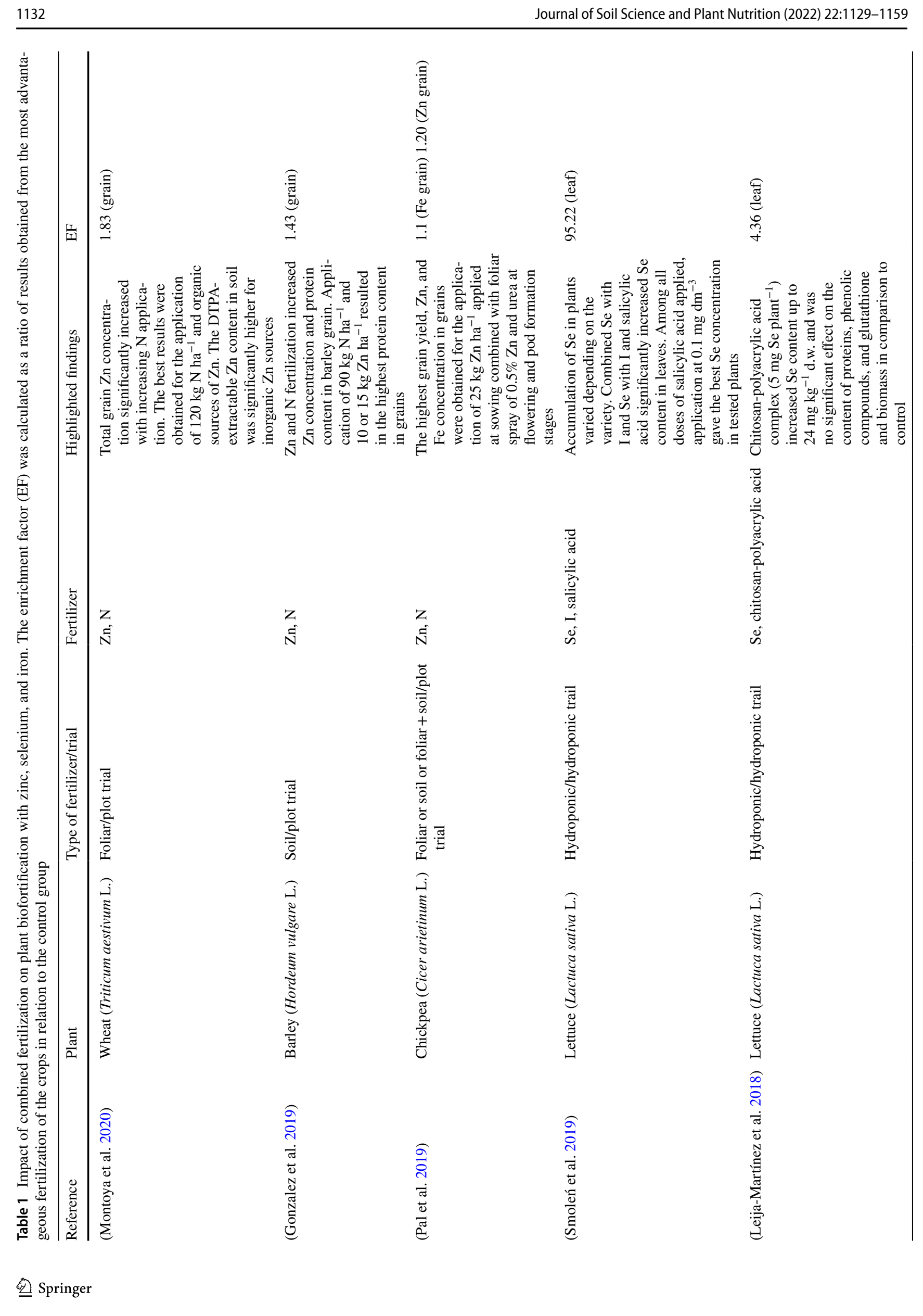




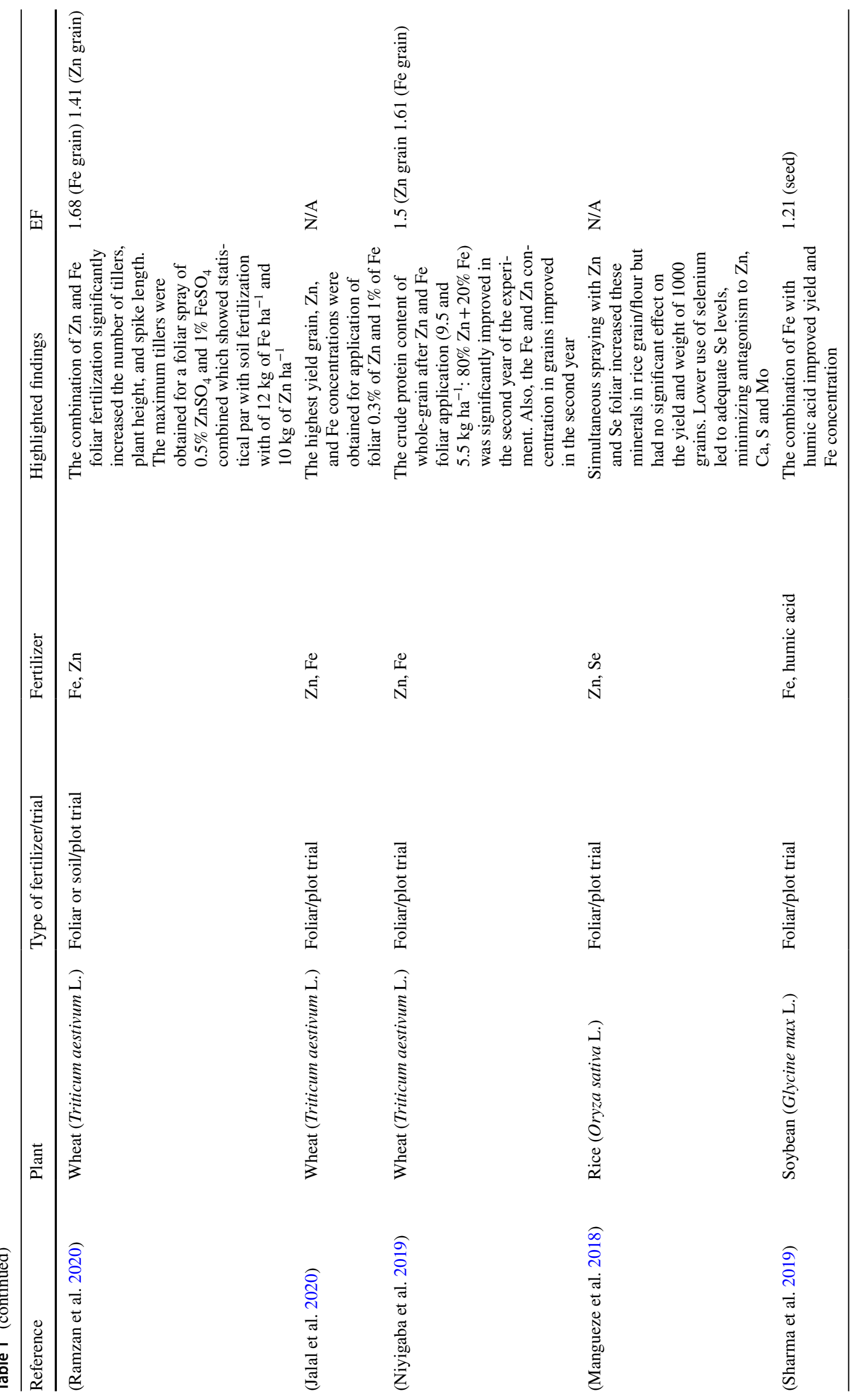




\subsection{Special Fertilizer}

\subsubsection{Biofertilizer}

Combining $\mathrm{Zn}, \mathrm{Se}$, and $\mathrm{Fe}$ in interaction with the application of plant growth-promoting bacteria (PGPR) and arbuscular mycorrhizal fungi (AMF) is beneficial for the development of the environmentally friendly biofertilizers used for the production of crops enriched in microelements. PGPR mobilizes the nutrients by various mechanisms including acidification, chelation, the release of organic acids, and exchange reactions (Triticum et al. 2015). Furthermore, the mechanism also strictly depends on applied PGPR and the chemical form of micronutrients, i.e., oxides, phosphates, or carbonates. Among plant growth-promoting bacteria (PGPR), Bacillus is the most popular for microelements biofortification. Bacillus aryabhattai and B. subtilis were used to enrich maize in $\mathrm{Zn}$ (Mumtaz et al. 2018). The presence of Bacillus was found to enrich solubilization of unavailable $\mathrm{Zn}$, as the microbial strains favor the formation of organic acids available for plants. As a result, the uptake of $\mathrm{N}, \mathrm{P}, \mathrm{K}$, and Fe can also be improved resulting in increased root length, dry weight of the plant, and even chlorophyll content. However, Padash et al. (2016) observed a decrease in Fe level after solubilization of $\mathrm{Zn}$ with Piriformospora indica. Bacillus pichinotyi-YAM2, Bacillus cereus-YAP6, and Bacillus licheniformis-YAP7 were tested for Se and Fe biofertilizers in wheat (Yasin et al. 2015a, 2015b). In a study conducted by Padash et al. (2016), the inoculation of fungi Piriformospora indica with $\mathrm{Zn}$ increased $\mathrm{Zn}$ level in lettuce. Fungus Rhizophagus intraradices can increase the root adsorption surface via hyphae. Thus, a significant increase in Se content in shallot and chickpea was obtained (Golubkina et al. 2019, 2020), while Pantoea dispersa MPJ9 and Pseudomonas putida MPJ6 were used for mung bean biofortification with $\mathrm{Fe}$, resulting in its content increase up to $100 \mathrm{mg} \mathrm{dm}^{-3}$ for MPJ9 after 60 days, when compared to control (30 ppm) (Patel et al. 2018). The positive effect on grain $\mathrm{Zn}$ concentration was observed for $\mathrm{Zn}$ inoculation with Rhizophagus irregularis above $150 \mathrm{mg} \mathrm{Zn} \mathrm{kg}^{-1}$ of soil (Tran et al. 2019). Further details about applications of Zn, Se, and Fe with microbes and impacts on microelements accumulation and physiological parameters of crops are presented in Table 3.

\subsubsection{Nanofertilizer}

$\mathrm{Zn}, \mathrm{Fe}$, and Se nanoparticles (NPs) can be synthesized in several ways. For example, Subbaiah et al. (2016) synthesized $\mathrm{ZnONPs}$ with a size about of $25 \mathrm{~nm}$ and negative zeta potential of $39.6 \mathrm{mV}$ by oxalate decomposition technique. The chitosan and sodium tripolyphosphate were used for the synthesis of positive charge $(42 \mathrm{mV})$ of the zinc complexed chitosan NPs (Deshpande et al. 2017). In a study proposed by Hussein et al. (2019), the SeNPs with a size of about 10-30 nm were synthesized by mixed sodium selenite with ascorbic acid. SeNPs were also stabilized by polyvinylpyrrolidone (PVP) and ascorbic acid with a diameter of about $70 \mathrm{~nm}$ were studied by Siddiqui et al. (2021) The origin of Se formation at the nanoscale was characterized using spectrophotometer UV-VIS (peak at wavelength $400 \mathrm{~nm}$ described selenium formation at nano size). The application of $\mathrm{Cu}, \mathrm{Fe}$, and $\mathrm{Zn}$ NPs mixed with urea-modified hydroxyapatite (diameter about $38.21 \mathrm{~nm}$ ) was studied by Tarafder et al. (2020).

Uptake, translocation, and accumulation of NPs depend on plant species and characteristics of NPs like size, chemical configuration, stability, and concentration. Du et al. (2019) showed inhibited effect of ZnONPs on the germination rate of wheat. By contrast, the same dose on ZnONPs has no significant effect on corn and cucumber germination with a significant decrease of root elongation (Zhang et al. 2015). In the study performed by Subbaiah et al. (2016), the highest germination percentage of corn was observed at $1500 \mathrm{mg} \mathrm{dm}^{-3}$ of ZnONPs.

The idea of decreasing the particle size of applied fertilizer is to deliver the "right dose of nutrients" in the "right place" and at the "right time." Additionally, reducing the size of the particles leads to the increase in specific surface area of particles, thus the contact area of fertilizers with the plants will be increased resulting in the higher nutrient uptake by the plants in comparison to applied commercial fertilizers. The effect of Fe as nano and bulk Fe complex (Fe(III)-EDTA) applied at the same dose was studied under hydroponic conditions under Fe-deficient in tobacco cultivation (Bastani et al. 2018). It was found that the dry weight of the plant in 2 weeks after the application was about three times higher for nano $\mathrm{Fe}$ in comparison to bulk Fe. Elanchezhian et al. (2017) suggested that the application of FeNPs can significantly decrease the amount applied commercial Fe-fertilizers maintaining the proper growth and metabolism of crops.

Du et al. (2019) compared the effects of foliar ZnONPs and zinc sulfate at the same concentrations on the growth of wheat (Triticum aestivum $\mathrm{L}$.). The highest $\mathrm{Zn}$ accumulation in grain was recorded with $100 \mathrm{mg} \mathrm{dm}^{-3}$ of ZnONPs which was about $29 \%$ higher when compared to applied 2000 ppm of zinc sulfate. Selenite, selenate, and Se nanoparticles (SeNPs) at doses $0.01-50 \mathrm{mg} \mathrm{dm}^{-3}$ were investigated for assessment of the phytotoxicity, accumulation, and transformation in garlic under hydroponic conditions. The highest Se content in roots was observed after application of selenite; however, the lowest translocation index of Se was observed in the case of application of SeNPs. The same results were observed for rice seedlings (Wang et al. 2020a). Tarafde et al. (2020) investigated the synthesis 


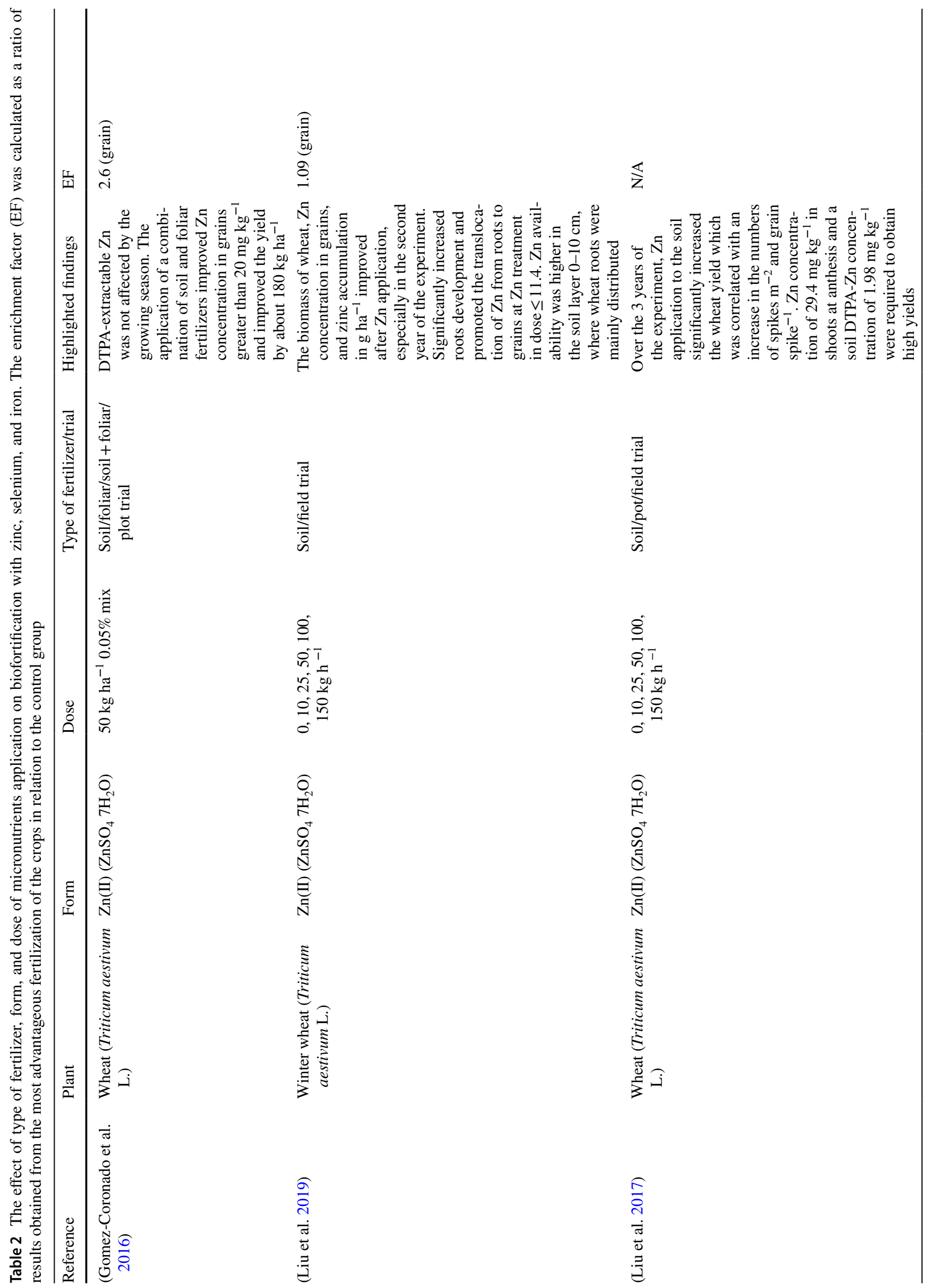




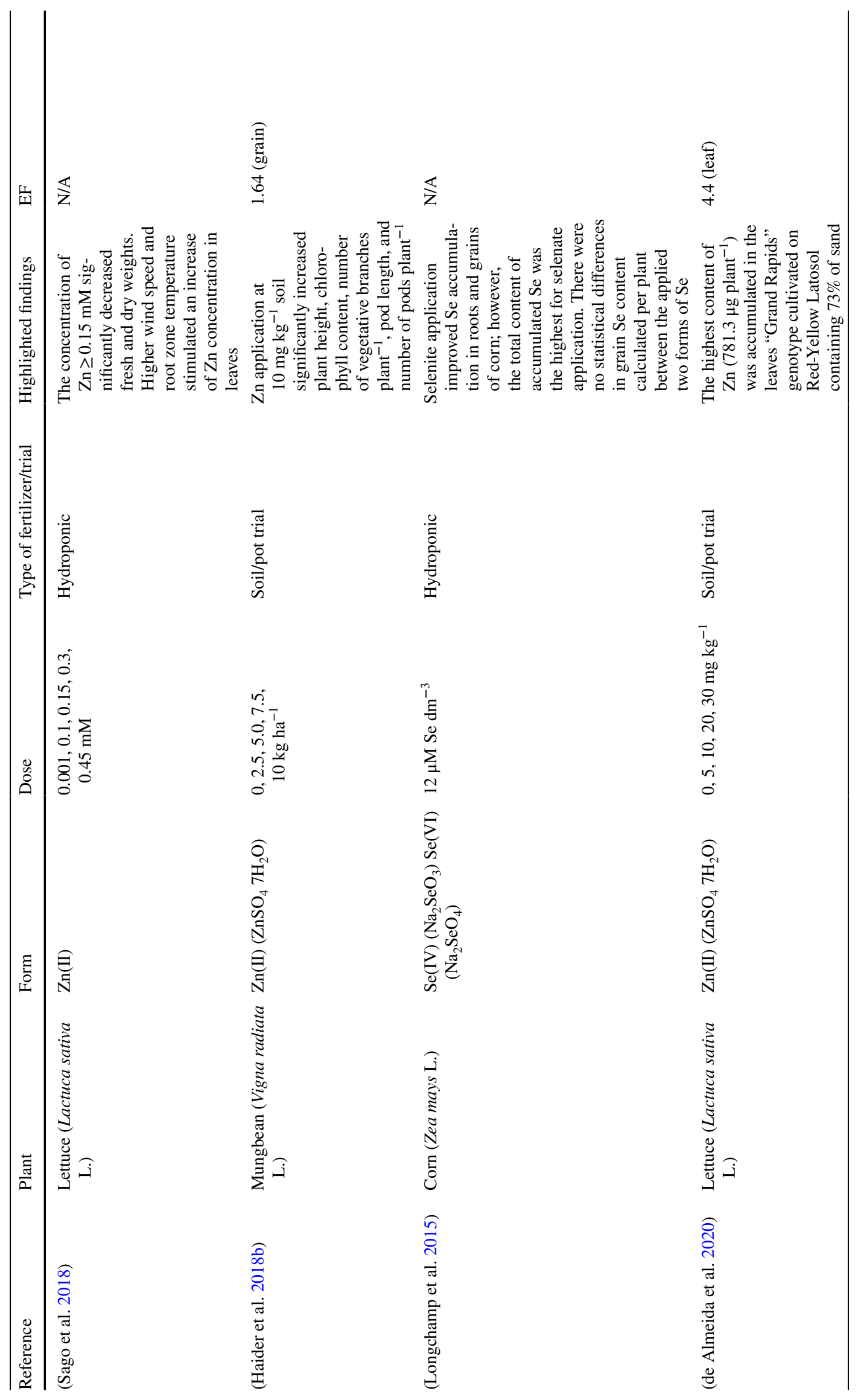




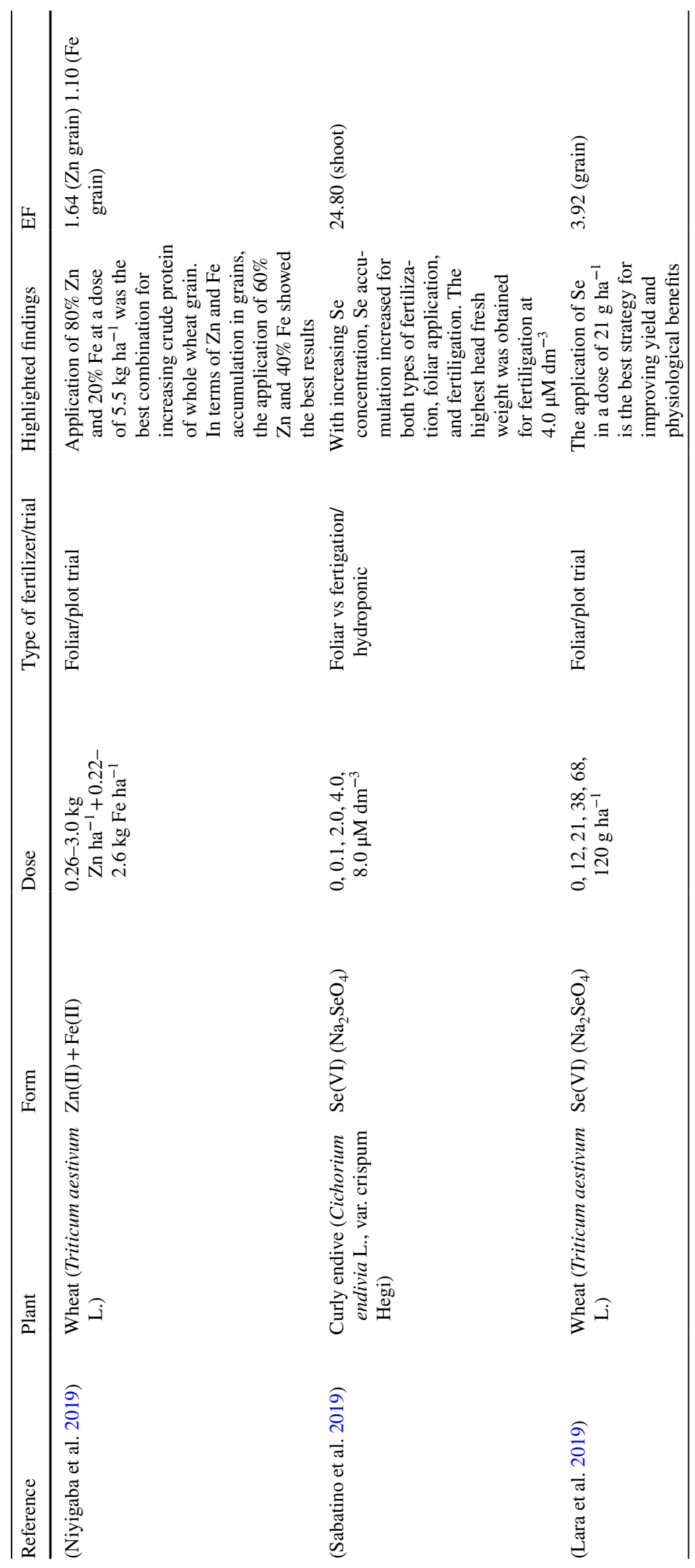




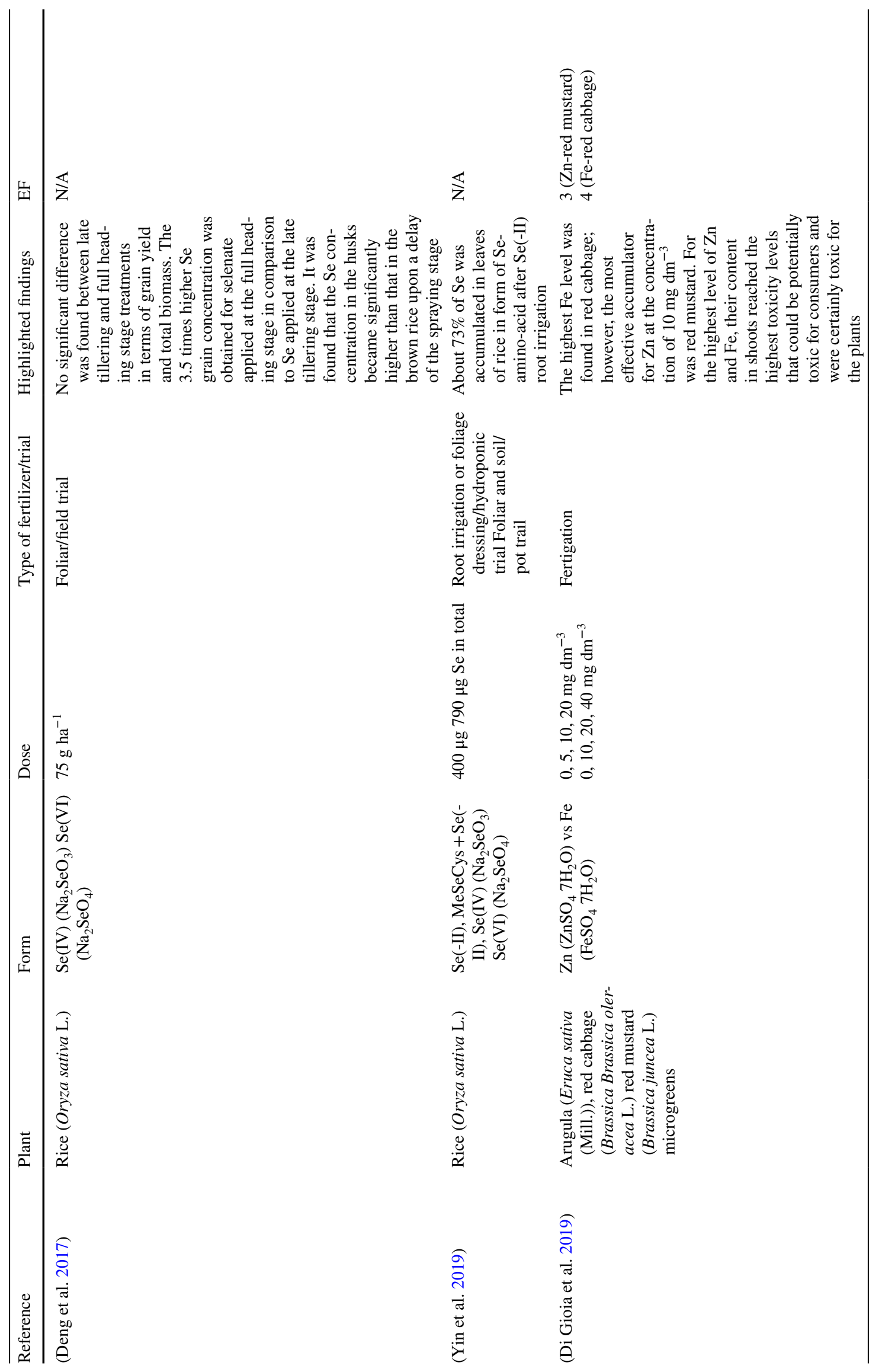




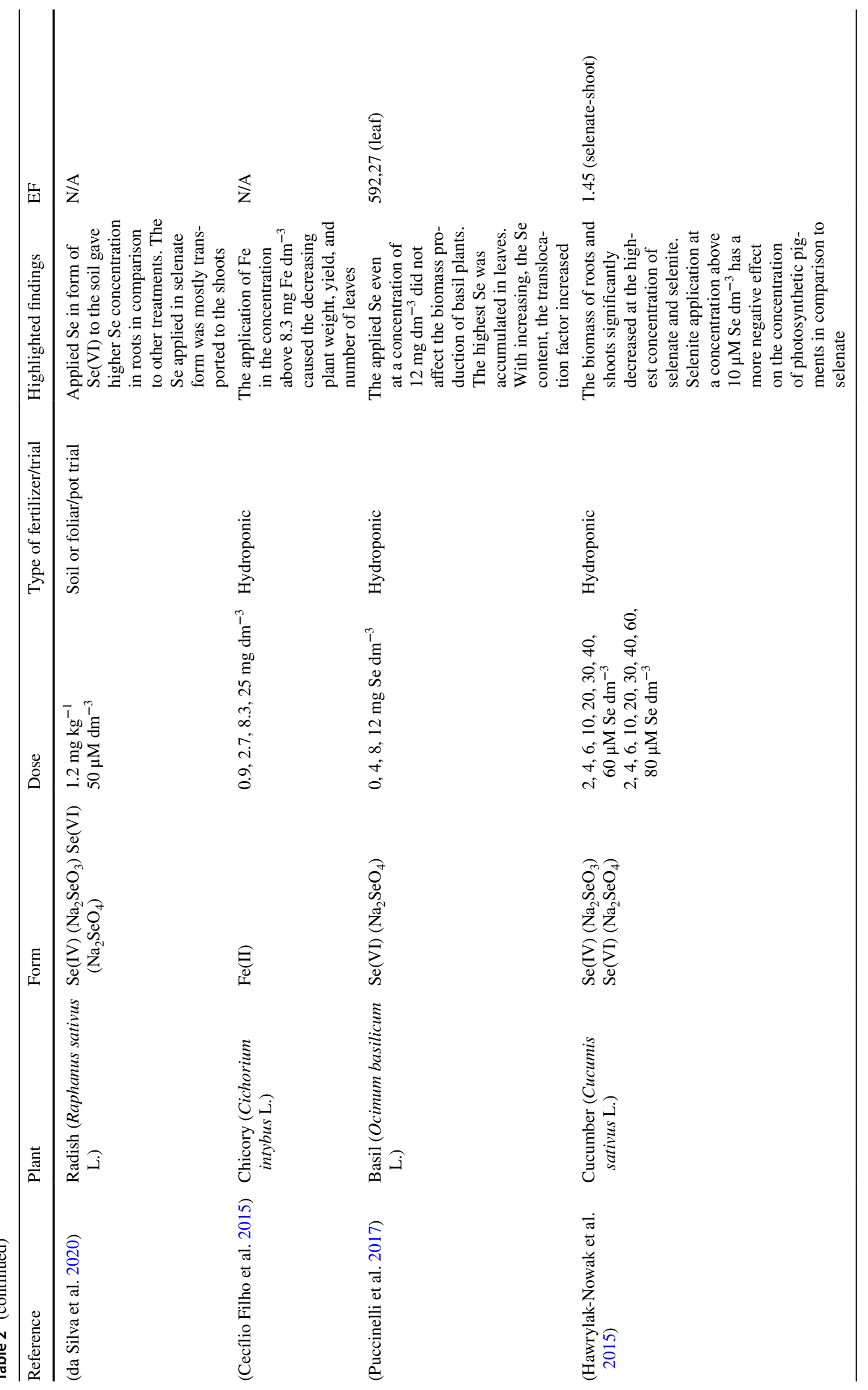




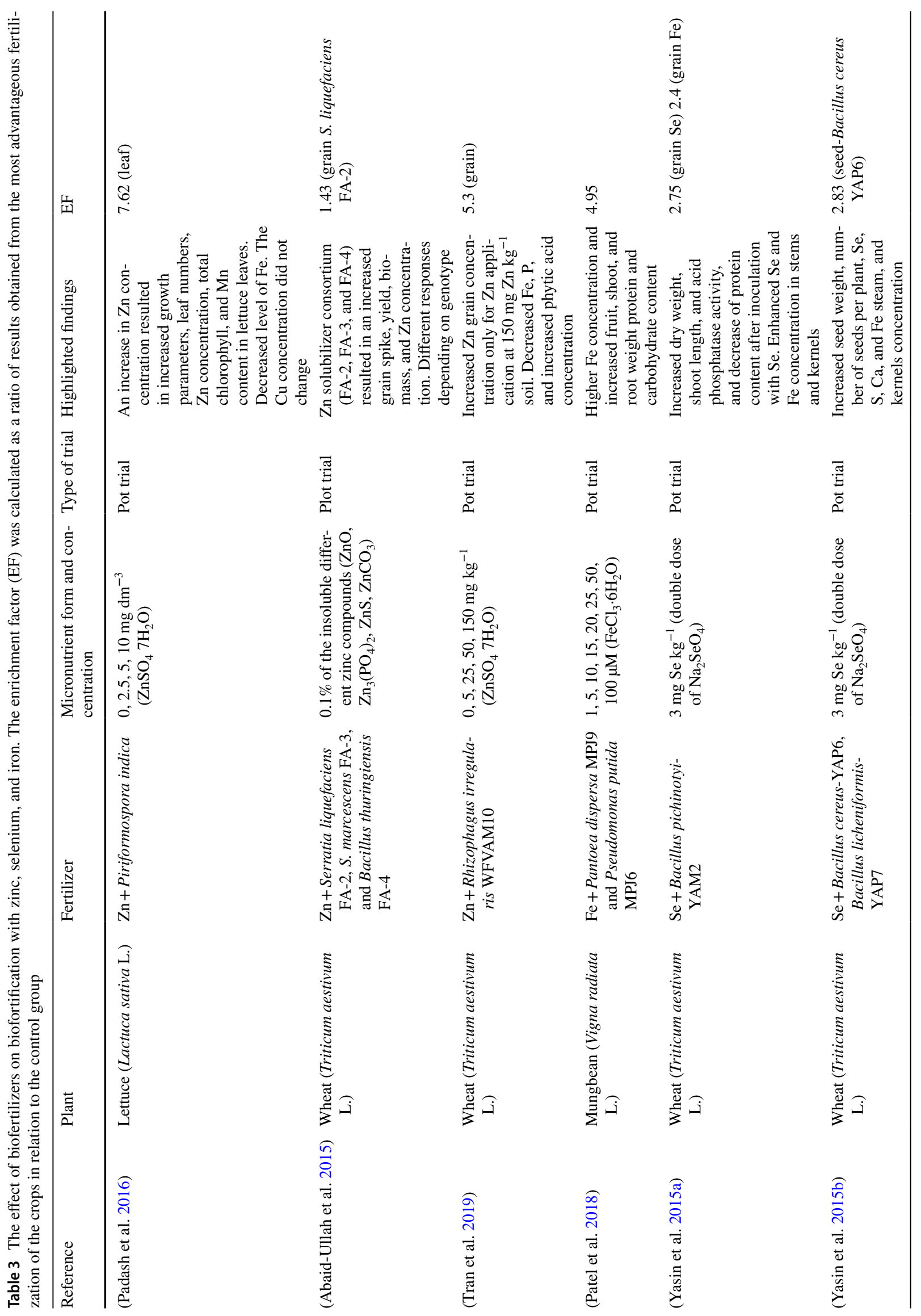




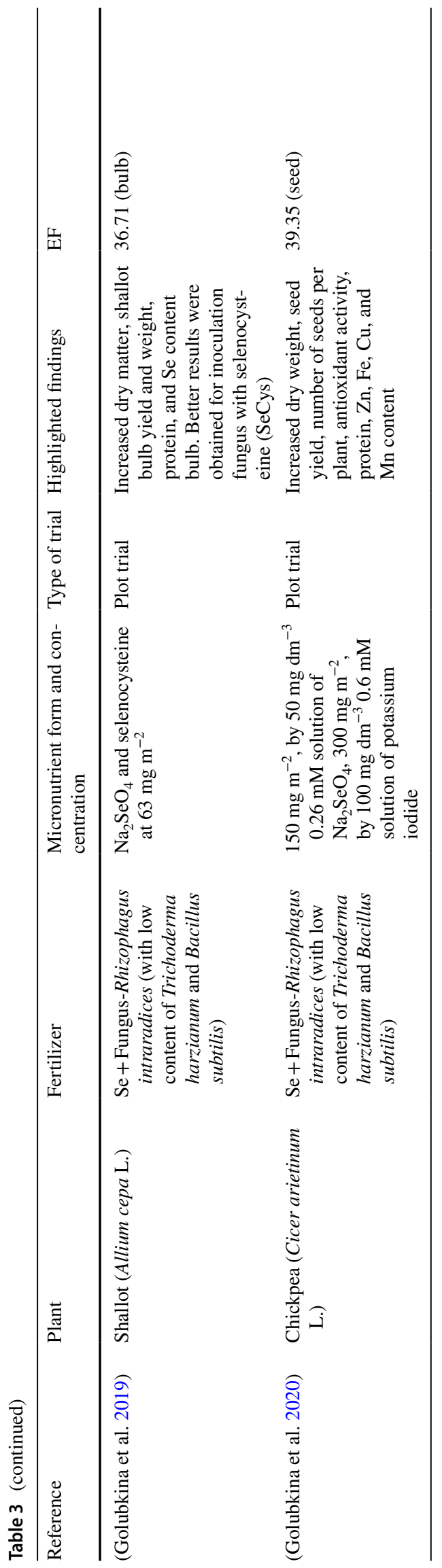

of the formulated slow-release fertilizers by incorporating hydroxyapatite, urea, and NPs of $\mathrm{Cu}, \mathrm{Fe}$, and $\mathrm{Zn}(\mathrm{HNF})$ and have compared their effect and commercial fertilizer on the accumulation of $\mathrm{Zn}, \mathrm{Fe}$ and $\mathrm{Cu}$ in Abelmoschus esculentus cultivation. Application of HNF about 16, 3, and 146 times improved total uptake of $\mathrm{Cu}, \mathrm{Fe}$, and $\mathrm{Zn}$, respectively, in comparison to commercial fertilizer.

The effect of NPs on biofortification with zinc, selenium, and iron is shown in Table 4.

\section{The Beneficial Effect of Se, Zn, and Fe on their Content and Nutritional Quality of Crops}

Biofortification with $\mathrm{Zn}$, Se, and Fe not only increases microelement content in the edible parts of crops, yield, and morphological parameters of crops but also have a beneficial impact on other nutritional parameters of crops like, i.e., increase of proteins, amino acids, phenolic acids, chlorophyll, carotenoids, and essential oil content. However, it is worth noting that success in crops enrichment by micronutrients can be achieved only when there are no negative symptoms on crops like, i.e., biomass reduction. $\mathrm{Zn}$, Se, and Fe fertilizers have an impact on the increase of the contentment of antioxidant compounds. Understanding stress physiology in plant growth can allow for the controlled synthesis of antioxidant compounds which are very valuable food compounds. For example, phenolic compounds are believed to scavenge and/or inhibit the production of ROS in the human body, thus preventing a critical step at the onset of carcinogenesis. The increase of antioxidant properties in plants can be caused by (i) the synthesis of not only phenolic compounds but also by other secondary metabolites exhibit antioxidant properties, (ii) the effect of microelements on the redox metabolism of glutathione (GSH) and enzymes involved in GSH metabolism, and (iii) the direct antioxidant effect microelement and its organic metabolites (Skrypnik et al. 2019).

It was found that application of Se to the nutrient solution at a dose of $12 \mathrm{mg} \mathrm{dm}^{-3}$ at the first and second cut has a significant effect on increased total phenol content in leaves basil. There were no significant differences in antioxidant capacity, rosmarinic acid content, total chlorophyll content, and leaf biomass between Se application and control (Puccinelli et al. 2020). The same results were obtained by Skrypnik et al. (2019) but for lower Se concentration (up to $0.78 \mathrm{mg} \mathrm{dm}^{-3}$ ). Contrary, Edelstein et al. (2016) noted that in order to avoid the reduction of the yield of basil, Se concentration in nutrient solution should be lower than $0.25 \mathrm{mg} \mathrm{dm}^{-3}$. Differences in Se accumulation could be different in varieties of basil. Two varieties of basil were tested on essential oil and Se content after foliar Se fertilization. 
The "Red Rubin" variety distinguished higher fresh phytomass yield and about two times higher Se content in leaves compared to the "Dark Green" variety; however, the content of essential oil was higher in "Dark Green" variety (Mezeyova and Hegedusova 2016). In the study conducted by Barátová et al. (2015), the variety of "Red Opal" had greater polyphenol content at first and second cut than "Dark Green."

Two varieties of lettuce were studied under hydroponic conditions with increasing Fe concentration. The accumulation of $\mathrm{Fe}$ of both varieties increased with increasing dose of Fe; however, the variety of "Red Salanova" performed the higher phenolic acids as well as phenolic content compared to "Green Salanova." Additionally, the significantly increased carotenoid content was observed only for the red lettuce variety. It is worth noting that only Fe applied at

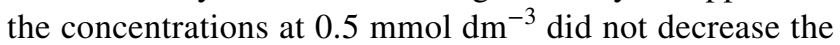
fresh and dry biomass of lettuce per plant (Giordano et al. 2019). Contrary, the application of $\mathrm{Zn}$ at the concentration of $0.45 \mathrm{mmol} \mathrm{dm}^{-3}$ significantly decreased these parameters in the red variety of lettuce (Sago et al. 2018).

Out of all types of crops, those enriched with sprouted seeds and microgreens deserve particular attention as they are a natural source of cancer preventive compounds (Park et al. 2015; Turner et al. 2020). Their biofortification gives the possibility to self-produce nutrient-dense plants in a very short time with the use of simple soilless systems. Se in the form of selenate at concentration 4 and $8 \mathrm{mg} \mathrm{dm}^{-3}$ significantly improved germination index, Se content, antioxidant capacity, and dry/fresh weight of microgreens of basil (Puccinelli et al. 2019a, b). The concentration of Se in microgreens was about 2.2 times higher than in leaves of maturity basil. This suggests that microgreens have a higher nutritional value and greater health benefits compared to mature leafy vegetables. The increased antioxidant capacity detected in the Se-enriched microgreens is in agreement with the results obtained in P. oleracea (Puccinelli et al. 2021a) and Ocimum basilicum L. Coriandrum sativum L., and Allium fistulosum L. (Newman et al. 2021). The application of selenate and selenite at $100 \mu \mathrm{M} \mathrm{dm}^{-3}$ was tested on three varieties of broccoli. The results showed that the application of selenate improved anthocyanin and ascorbic acid content in tested broccoli varieties, whereas the selenite was more effective in the accumulation of flavonoid content. There were no significant differences between the form of applied Se for total phenolic content; however, in both cases, the total phenolic content was lower than control (Tian et al. 2016). In the study conducted by Vicas et al. (2019), application of SeNPs even higher concentrations did not affect changes in the total phenol content. On the other hand, it was found that both the soaking and spraying pea seeds with $\mathrm{Zn}$ significantly increased the total phenolic content up to $\mathrm{Zn}$ application at $40 \mathrm{mg} \mathrm{dm}^{-3}$ (Lingyun et al. 2016).
The effect of biofortification with $\mathrm{Zn}, \mathrm{Se}$, and $\mathrm{Fe}$ on plant metabolism is provided in Table 5 .

\section{The Influence of Biofortification with Zn, Se, and Fe on the Defense of Plants Against Abiotic Stress}

Abiotic stresses such as salt, high/low temperature, heavy metal, and drought cause, i.e., overproduction of reactive oxygen species (ROS) and inducement of oxidative stress in plants. It was evidenced that biofortification with $\mathrm{Zn}$, $\mathrm{Se}$, and $\mathrm{Fe}$ using different types and forms of fertilizer can reduce the damage caused by oxidative stress by an increase of ROS-scavenging enzymes like (superoxide dismutase (SOD), ascorbate peroxidase (APX), catalase (CAT), glutathione peroxidase (GPX), monodehydroascorbate reductase (MDHAR), dehydroascorbate reductase (DHAR), glutathione reductase (GR), glutathione S-transferase (GST), and peroxiredoxin (PRX) content in different sites of plant cells (Amira et al. 2015; Noreen et al. 2020). The application of microelements also enhanced the content of nonenzymatic antioxidants such as GSH, ASA, carotenoids, and proline which are also crucial for the maintenance of ROS homeostasis in the plant. In addition, to maintain the balance of ROS in plants, the application of micronutrients significantly decreased the level of heavy metals in plant tissues, and improved morphological growth parameters and $\mathrm{Zn}, \mathrm{Se}$, and $\mathrm{Fe}$ concentration in edible parts of crops.

Of all toxic heavy metals, the most frequently studied was the alleviation of the Cd stress which is recognized as one of the most hazardous environmental contaminants. Rizwan et al. (2019) found that soaking wheat seeds with ZnNPs and FeNPs significantly decreased wheat grain Cd concentration (about 82\%). Similar results were obtained for soil and foliar application of FeONPs (Hussain et al. 2019). Wheat seeds, with different concentrations of intrinsic $\mathrm{Zn}$, were planted in artificially $\mathrm{Cd}$ contaminated soil. The lowest grain $\mathrm{Cd}$ concentration was observed for crops that grow from seeds with high intrinsic $\mathrm{Zn}$ cultivated on soil enrichment with Zn and biochar.

It has been estimated that the one billion hectares of arid and semi-arid areas of the world remain barren due to salinity or water scarcity (Sahab et al. 2021). The application of Se can significantly mitigate the toxic influence of salt stress. For example, Se application at a low concentration of $5-10 \mathrm{mg} \mathrm{dm}^{-3}$ under salinity conditions significantly increased the antioxidant enzymes activities, the total phenol and flavonoid content, and the enhancement of the $\mathrm{K} / \mathrm{Na}$ ratio in grapes (Karimi et al. 2020). The application of SeNPs at the concentration of $10 \mathrm{mg} \mathrm{dm}^{-3}$ also increased about 1.85 times enzymatic antioxidant content (APX, GPX, CAT, and SOD) in tomato fruits cultivated on 


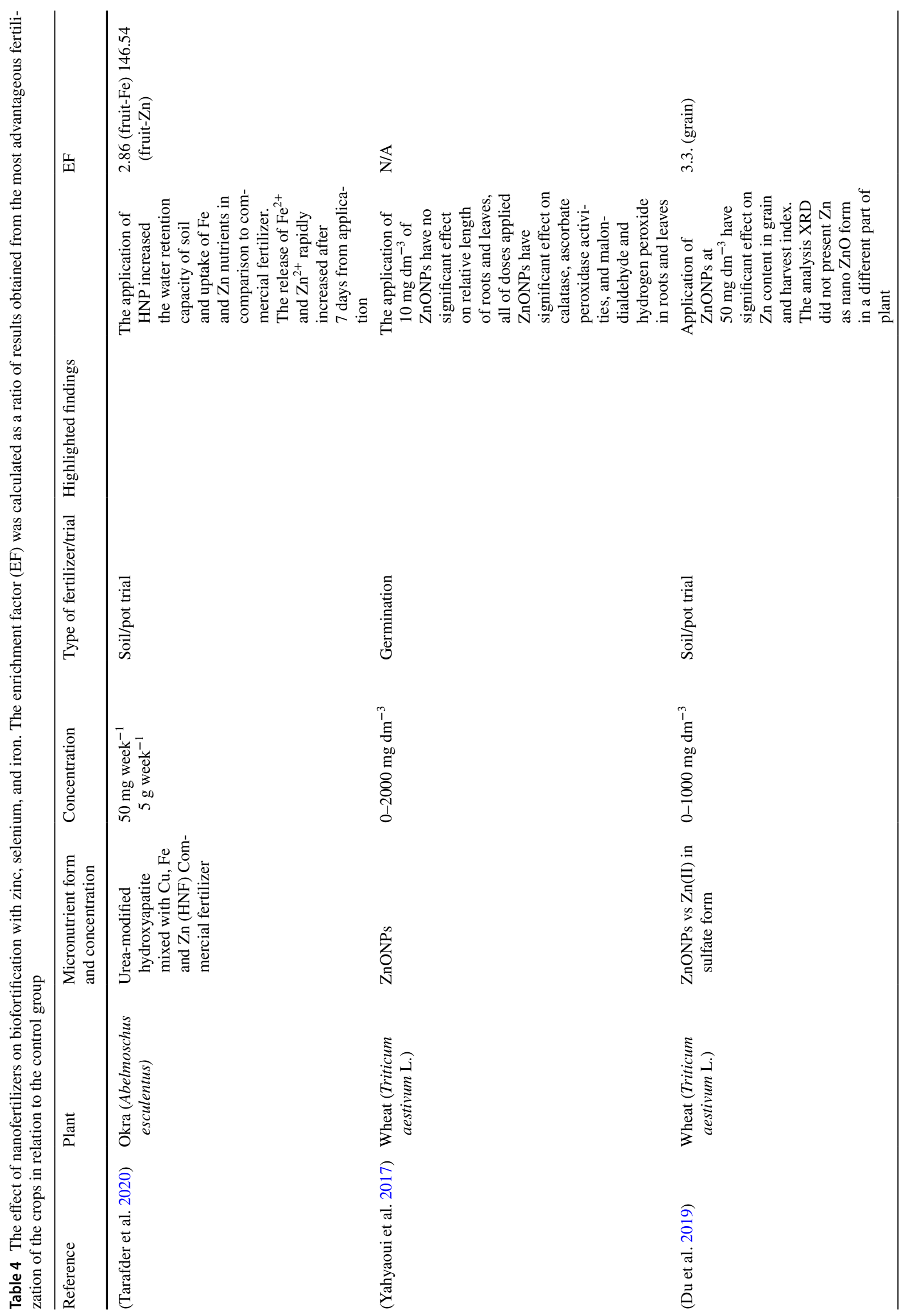




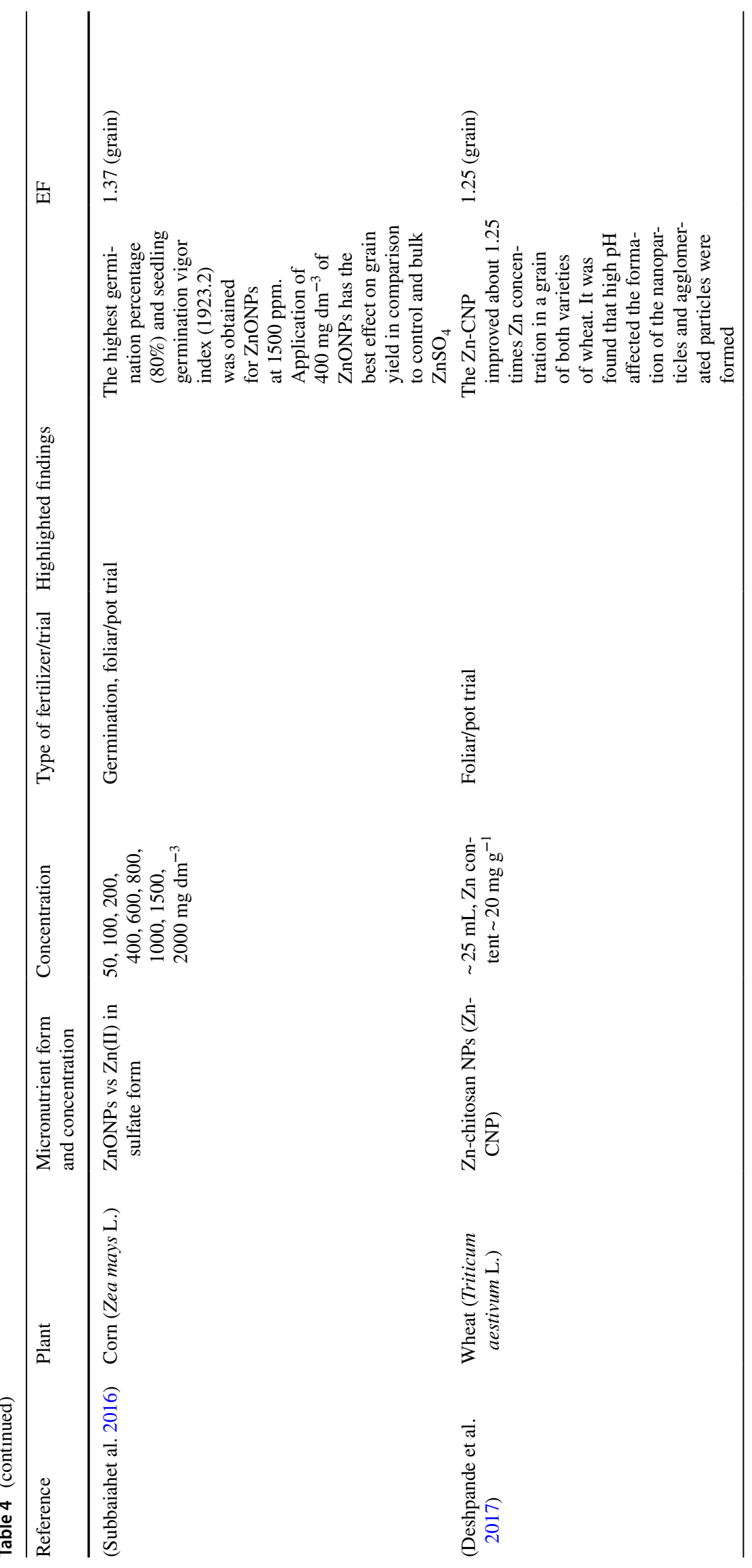




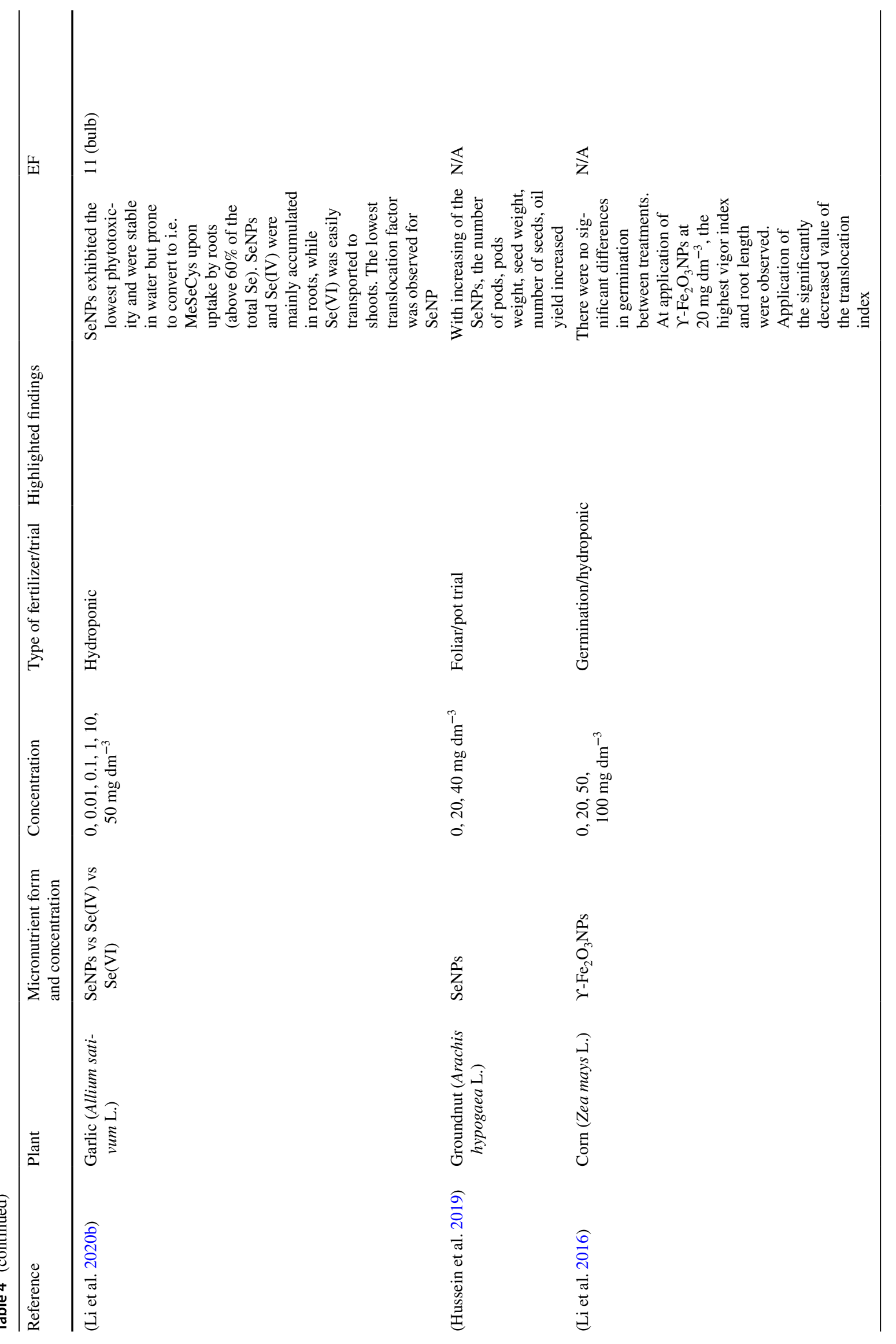


salinity (Morales-Espinoza et al. 2019). The minimalized consequence of salt stress in plants was also mitigated by a combination of $\mathrm{Zn}$ with ascorbic acid in barley (Noreen et al. 2020).

It is worth noting that numerous studies on the impact of micronutrients on alleviation of negative effects of abiotic stress have been performed under laboratory conditions, and only a few were conducted in natural, field conditions (Nawaz et al. 2017). Table 6 summarizes the influence of biofortification with $\mathrm{Zn}, \mathrm{Se}$, and $\mathrm{Fe}$ on the adaptation of plants under stress conditions.

\section{Future Perspectives and Strategies}

Agronomic biofortification is the most promising way to successfully alleviate micronutrient malnutrition by increasing the mineral content in the crops and simultaneously enhancing their bioavailability by reducing antinutritional compounds and/or enhancing the concentration of mineral absorption promoters. $\mathrm{Zn}, \mathrm{Se}$, and Fe biofortification efforts should consider the concentration and species of micronutrients accumulated in the plant in relation to the effects that such micronutrients enrichment could exert on the production of health-beneficial and/or stress-defense compounds. Additionally, the balance between the production and nutrient requirements of $\mathrm{Zn}, \mathrm{Fe}$, and Se should be included in considerations of sustainable intensification.

Based on the collected data there is still a lot of missing information that should be considered when planning future research:

1 most of the research into biofortification with micronutrients was conducted in laboratory conditions under strictly controlled environmental factors and it is important to verify those results under a wide variety of environmental conditions;

2 there is a lack of information in the collected data about the form of application of fertilizer on the transfer of microelements, e.g., granules vs. liquid form vs. encapsulated fertilizers. What is also missing is information around the influence of soil properties on the release of micronutrients during long-term application;

3 in many studies, there is also a lack of basic characteristics of soils, like $\mathrm{pH}$, the content of organic matter, salinity, and moisture which are very important factors regulating the form and concentration of micronutrients in the soil;

4 the total micronutrient content in plants is not always an appropriate indicator of its useful nutritional quality as the human body can absorb only a particular form and dose of micronutrients and only a few studies covered the determination of the form of compounds accumulated micronutrients;

5 further studies are required with more species and/or cultivars of the same species under variable growing conditions to define the best practice for $\mathrm{Zn}, \mathrm{Se}$, and Fe agronomic biofortification;

6 further research is required to estimate $\mathrm{Zn}, \mathrm{Se}$, and $\mathrm{Fe}$ bioavailability in biofortified microgreens, sprouts, and baby greens;

7 some papers proved that fertilization with more than one micronutrient gives better effects than applied alone. However, it is worth mentioning that is needed to reach fine-tune doses to obtain an adequate accumulation of micronutrients in edible parts of crops without limiting growth and quality parameters. More studies are required to gain an understanding of the antagonistic and competitive effects of nutrient elements on plant uptake of $\mathrm{Se}, \mathrm{Zn}$, and $\mathrm{Fe}$;

8 to achieve sustainable agricultural productivity, growers should switch from a high input-based production system to the cultivation of soil-plant-microbiom interaction-based systems. More work should be focused on:

- studying biological inoculants in the agriculture field under changing climatic conditions and competition by indigenous microorganisms

- better understanding the effect of plant beneficial rhizobacteria on the effective utilization of these microbes in mitigating various abiotic stresses

- studying promotion of plant growth with a combination of microorganism with a mix of micronutrients at different concentrations;

9) the increasing commercial use of NPs may result in unintended exposure to flora and fauna of the environment. Key aspects that influence toxicity in plants are the following: the concentration of NPs, particle size, surface area, stability, physicochemical properties, plant species, plant age/phenological stage, the medium of exposure, and dilution agent. The future research should be conducted utilizing the processes of translocation and accumulation of micronutrient NPs in crops. This area of research has not been studied adequately and much more studies have been performed up to the germination stage, providing only limited information. Due to the finite term of existence of NPs, there is a need to perform research under the stability of NPs in time. Additionally, from the environmental protection point of view, strict dosage and distribution control of NPs is a very important issue for ensuring that the application of NPs poses no potential risk for plants, animals, and humans. The application of NPs is a very promising way in crops 


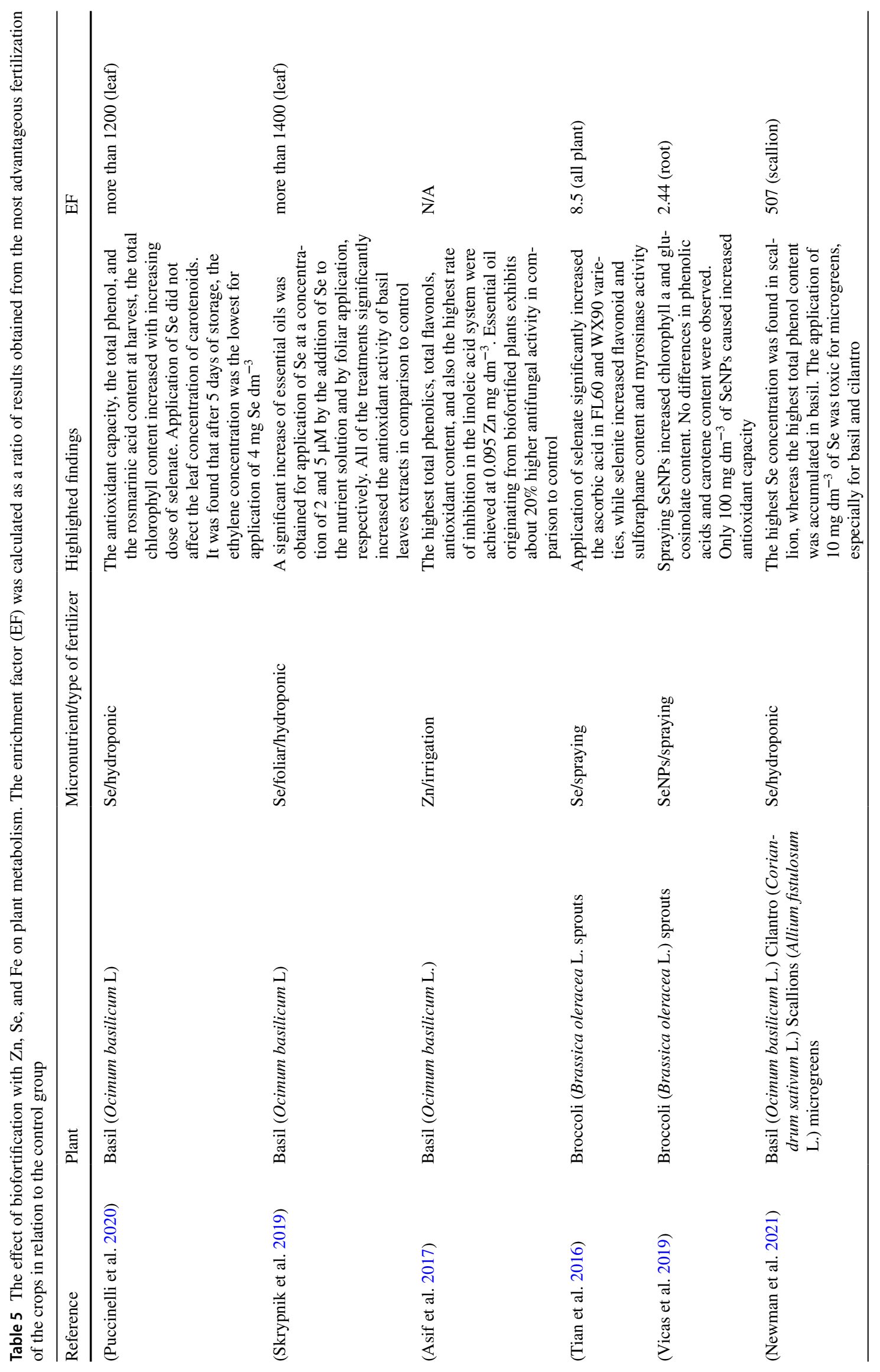




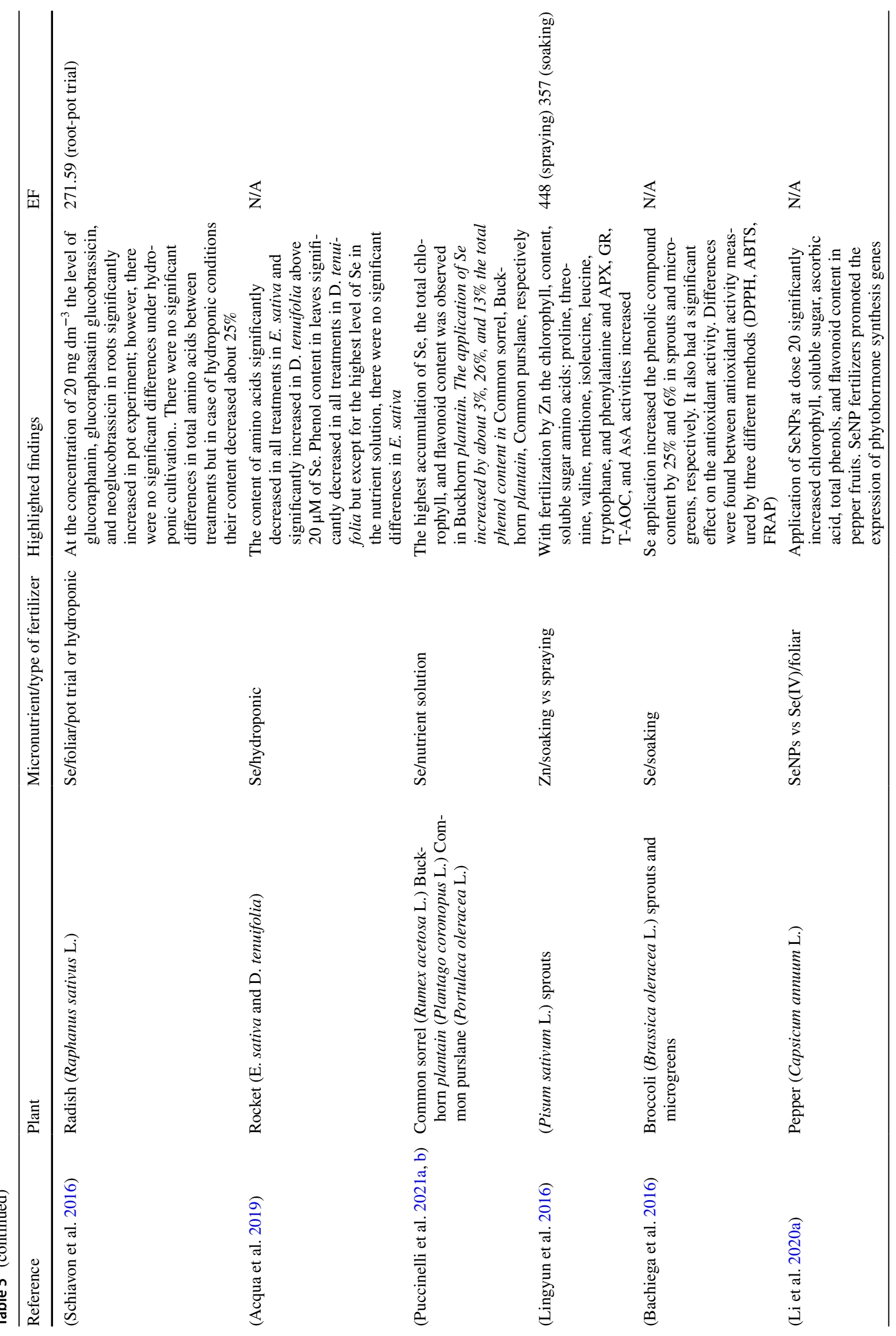




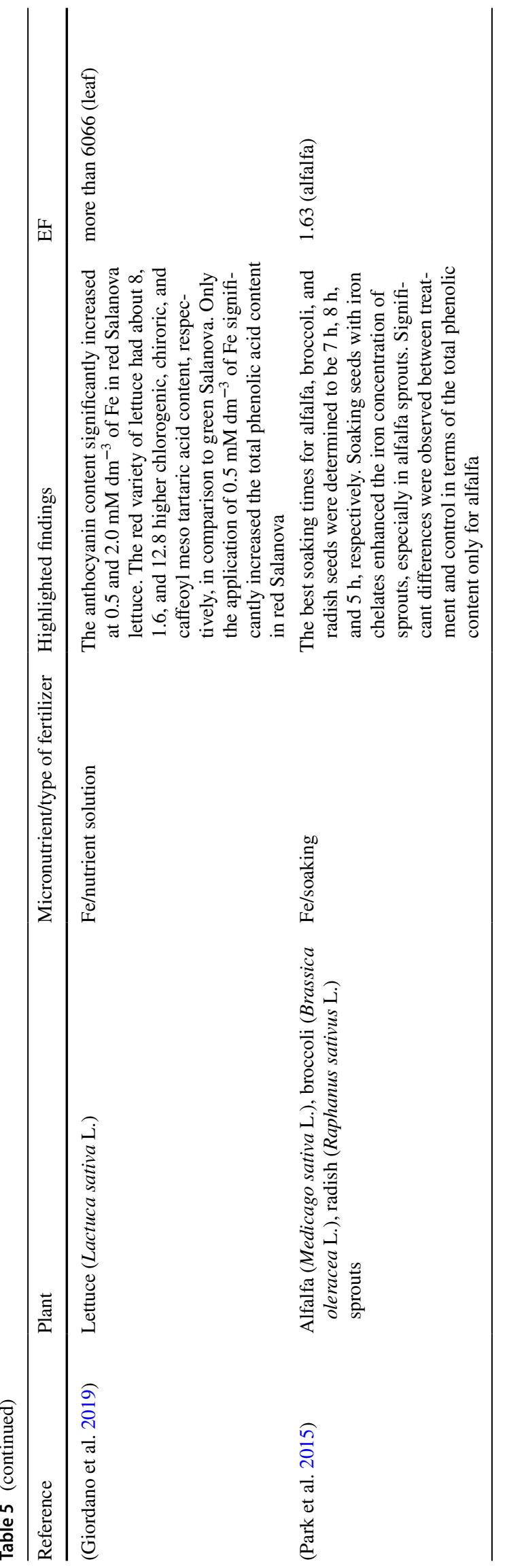

fertilization; however, the focus should be on the greener approach for the synthesis of metal oxide nanoparticles, which would, to some extent, help in limiting toxicity towards the environment;

10 ) it is quite easy to evaluate the responses of single species or a few plant species to $\mathrm{Se}, \mathrm{Zn}$, or Fe under the effect of one single stress in the laboratory. There are many factors in field conditions that are responsible for plant stress, the reaction of plants can differ in comparison to results obtained on a laboratory scale, and it is important to perform more experiments in field conditions. One of the main future challenges is to better recognize $\mathrm{Se}-, \mathrm{Zn}$-, and Fe-plant interactions under abiotic stress to reveal the beneficial role of these micronutrients. Furthermore, studies with full life cycles of plants are also needed, especially to better understand the impacts of NPs on heavy metal accumulation by plants grown in realistic contaminated soils.

\section{Conclusion}

Agronomic biofortification of staple and non-staple crops with $\mathrm{Zn}, \mathrm{Se}$, and $\mathrm{Fe}$ using mineral and organic fertilizers has an exceptional potential for a fight with hidden hunger worldwide. The review is focused on the state-of-art application of $\mathrm{Zn}, \mathrm{Se}$, and Fe fertilizers including the selection of the type of fertilizers (including nanofertilizers and biofertilizers), type and dose of applied micronutrients, and their accumulation by selected crops. Besides an insight into the application of $\mathrm{Zn}, \mathrm{Se}$, and $\mathrm{Fe}$ in terms of increasing the nutritional value of crops, the review also presents positive influence of micronutrients on alleviating the damage caused by abiotic stress.

The success of agronomic biofortification depends on many important factors and, although numerous papers have been published regarding $\mathrm{Zn}$, Se, and Fe fertilization and the effect of many factors on the effectiveness of agronomic biofortification, the understanding of this topic is still unclear. Based on collected literature, it could be concluded that more research should be performed concerning: field experiments with variable conditions and full life cycles of plants, the impact of soil properties on the release of micronutrients during long-term application, the determination of the form of compounds accumulated micronutrients in edible parts of crops, the reaction of species and/or cultivars of the same species on $\mathrm{Zn}, \mathrm{Se}$, and $\mathrm{Fe}$ fertilization and different ways of application fertilizer, an antagonistic and competitive effects of different factors on plant uptake of $\mathrm{Se}, \mathrm{Zn}$, and Fe, impact of biofertilizers and nanofertilizers on environment and accumulation in edible parts of crops, the impact of $\mathrm{Zn}, \mathrm{Se}$, and Fe on heavy metal 


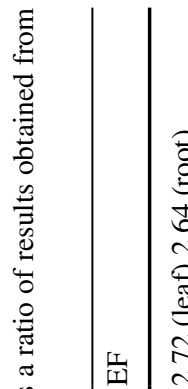

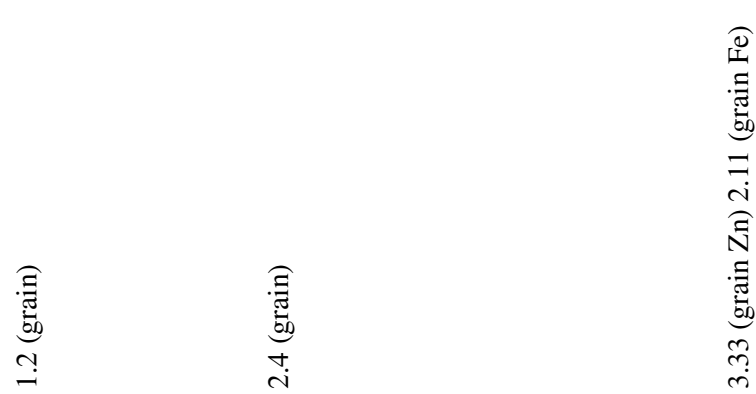

要

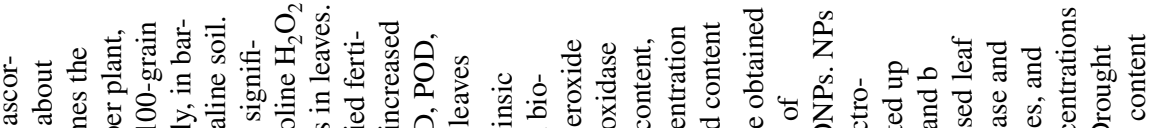

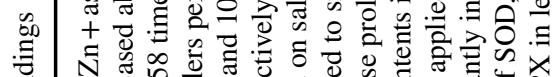

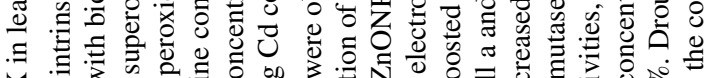

营

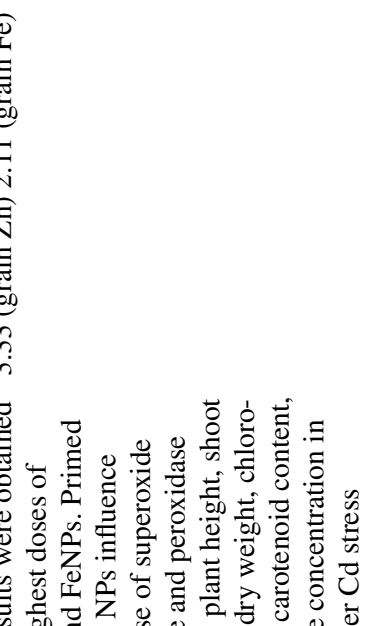

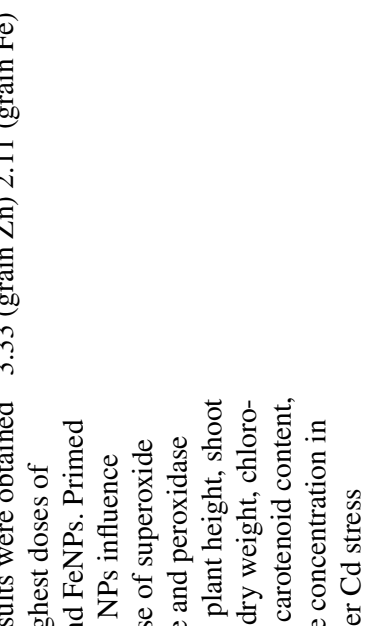

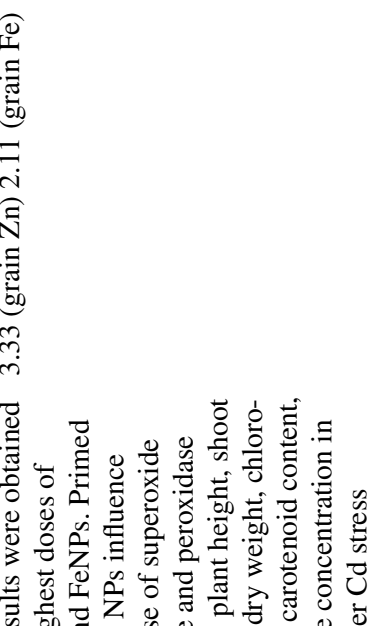

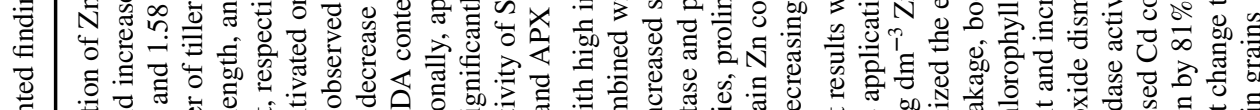

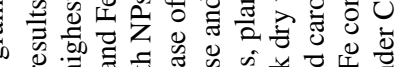

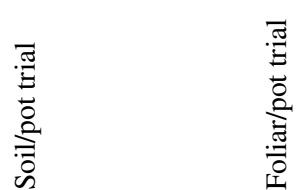

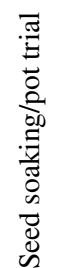




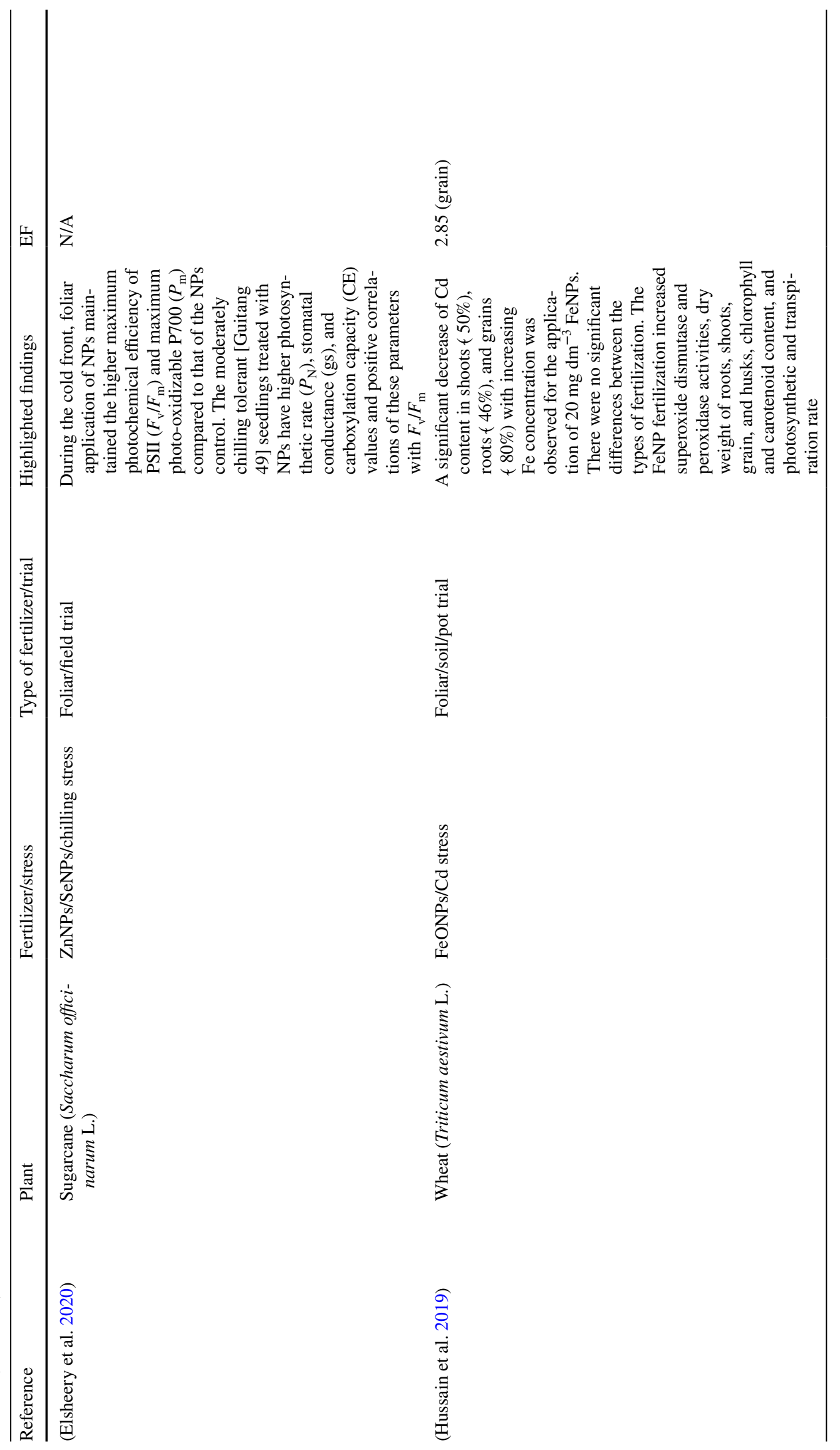




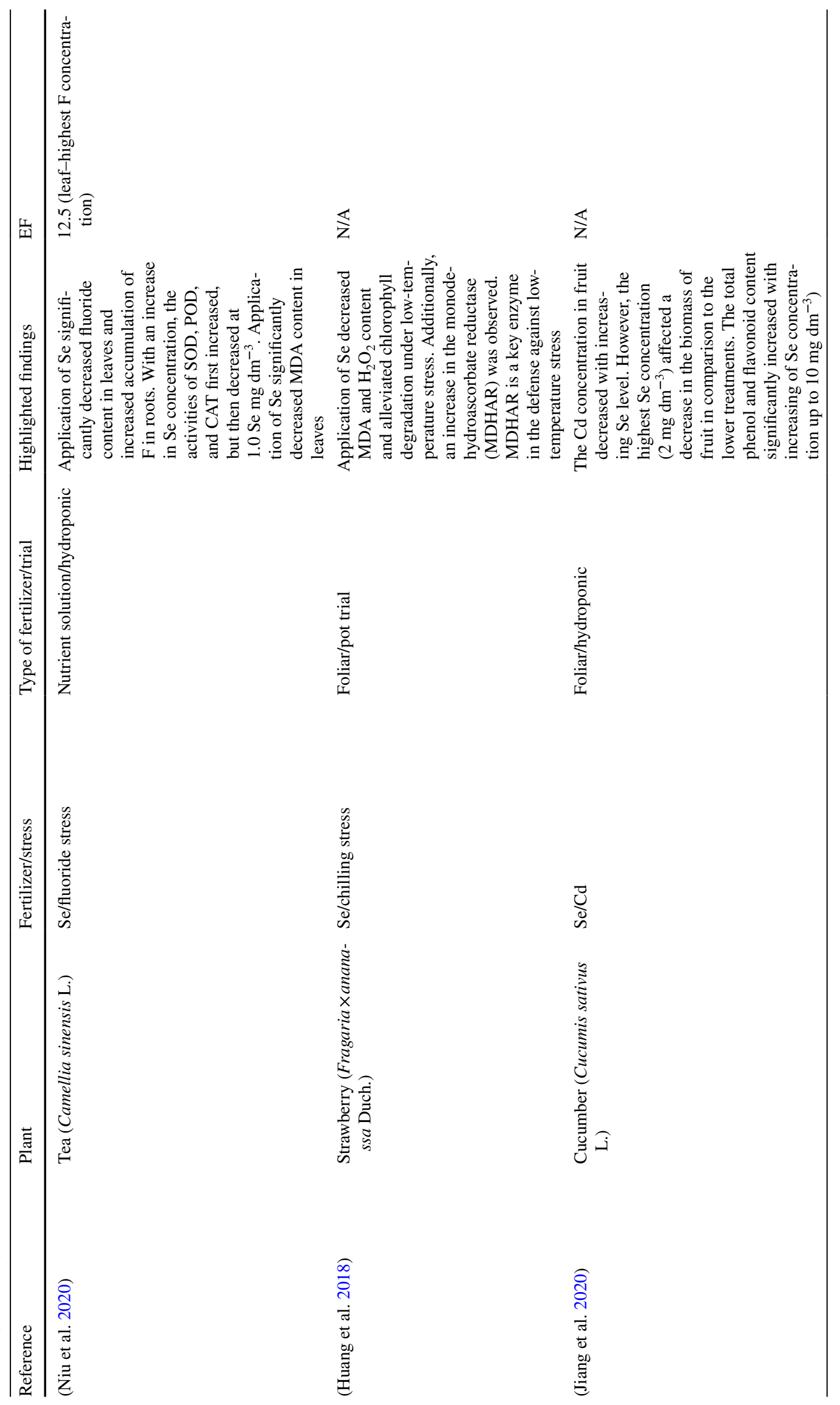




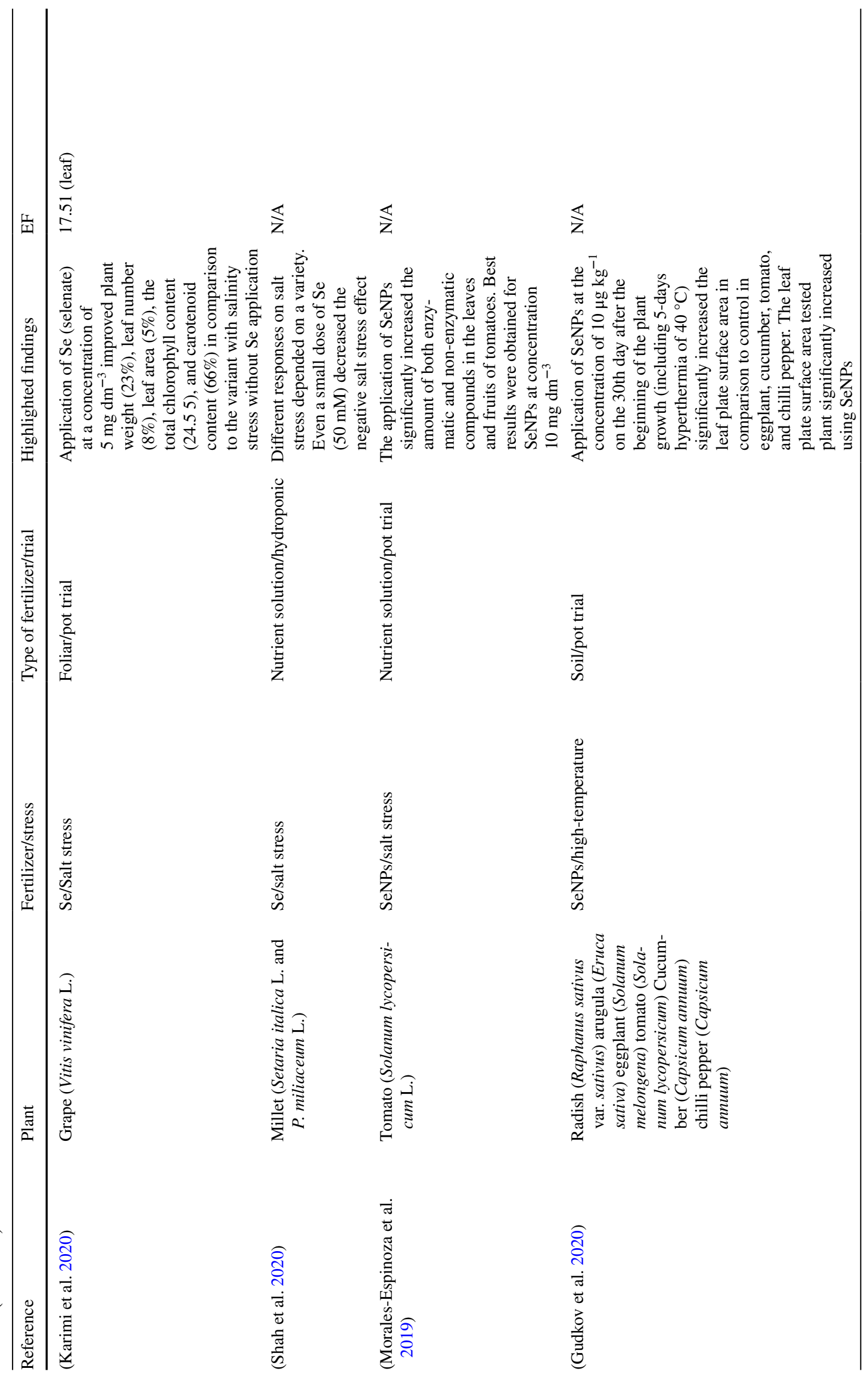




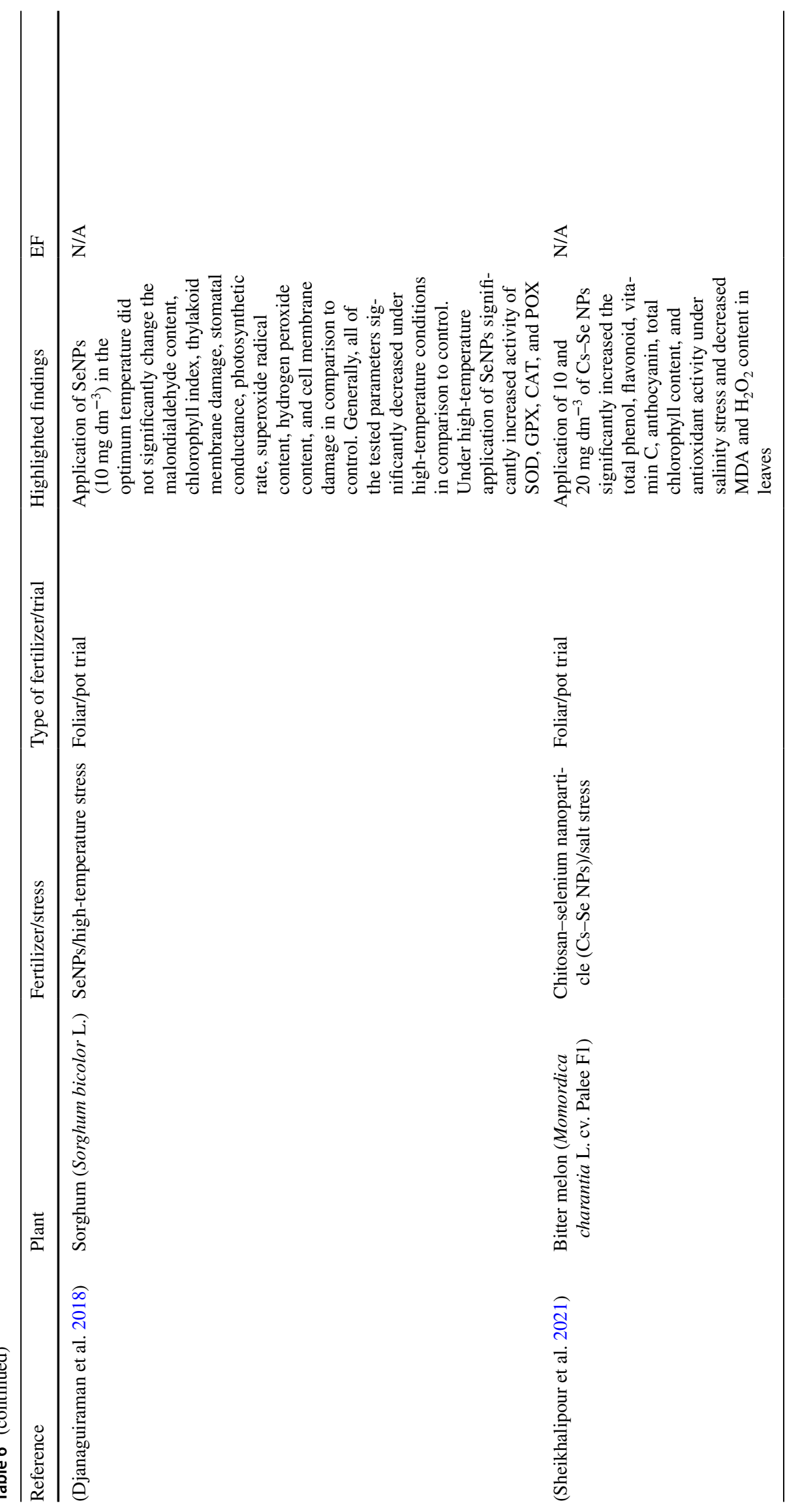


accumulation by crops especially grown in realistic heavy metals levels in the soil.

Author Contribution Idea for the article: J.S.; concept and design of the paper: J.S.; literature search: J.S.; writing original draft preparation: J.S.; review and editing: J.S., A.S-K, J.M., M. M.-H.

Funding Article was conducted under the project "Fly ashes as the precursors of functionalized materials for applications in environmental engineering, civil engineering and agriculture"-project is carried out within the TEAM-NET program of the Foundation for Polish Science POIR.04.04.00-00-14E6/18-00.

\section{Declarations}

Conflict of Interest The authors declare no competing interests.

Open Access This article is licensed under a Creative Commons Attribution 4.0 International License, which permits use, sharing, adaptation, distribution and reproduction in any medium or format, as long as you give appropriate credit to the original author(s) and the source, provide a link to the Creative Commons licence, and indicate if changes were made. The images or other third party material in this article are included in the article's Creative Commons licence, unless indicated otherwise in a credit line to the material. If material is not included in the article's Creative Commons licence and your intended use is not permitted by statutory regulation or exceeds the permitted use, you will need to obtain permission directly from the copyright holder. To view a copy of this licence, visit http://creativecommons.org/licenses/by/4.0/.

\section{References}

Abaid-Ullah M, Hassan MN, Jamil M, Brader G, Shah MKN, Sessitsch A, Hafeez FY (2015) Plant growth promoting rhizobacteria: an alternate way to improve yield and quality of wheat (Triticum aestivum). Int J Agric Biol 17:51-60

Acqua SD, Ertani A, Pilon-Smits EAH, Fabrega-Prats M, Schiavon M (2019) Selenium biofortification differentially affects sulfur two rocket species (Eruca Sativa Mill. and Diplotaxis Tenuifolia) Grown in Hydroponics. Plants 8:68. https://doi.org/10.3390/plant s8030068

Adrees M, Khan ZS, Hafeez M, Rizwan M, Hussain K, Asrar M, Alyemeni MN, Wijaya L, Ali S (2021) Foliar exposure of zinc oxide nanoparticles improved the growth of wheat (Triticum aestivum L.) and decreased cadmium concentration in grains under simultaneous Cd and water deficient stress. Ecotoxicol Environ Saf 208:111627. https://doi.org/10.1016/j.ecoenv.2020.111627

de Almeida H, Carmona VMV, Inocêncio MF, Furtini Neto AE, Cecílio Filho AB, Mauad M (2020) Soil type and zinc doses in agronomic biofortification of lettuce genotypes. Agronomy 10:124. https://doi.org/10.3390/agronomy10010124

Amira SS, Souad AEl-feky, Essam D, (2015) Alleviation of salt stress on Moringa peregrina using foliar application of nanofertilizers. J Hortic for 7:36-47. https://doi.org/10.5897/JHF2014.0379

Asif M, Nawaz H, Adnan M, Tabassum N, Kanwal N, Rashid N, Saleem M, Ahmad M (2017) Evaluation of the effects of Zinc on the chemical composition and biological activity of basil essential oil by using Raman spectroscopy. Ind Crop Prod 96:91-101. https:// doi.org/10.1016/j.indcrop.2016.10.058
Athar T, Khan MK, Pandey A, Yilmaz FG, Hamurcu M, Hakki EE, Gezgin S (2020) Biofortification and the involved modern approaches. J Elem 25:717-731. https://doi.org/10.5601/jelem. 2020.25.1.1911

Bachiega P, Salgado JM, De Carvalho JE, Ruiz ALTG, Schwarz K, Tezotto T, Morzelle MC (2016) Antioxidant and antiproliferative activities in different maturation stages of broccoli (Brassica oleracea Italica) biofortified with selenium. Food Chem 190:771-776. https://doi.org/10.1016/j.foodchem.2015.06.024

Barátová S, Mezeyova I, Hegedusová A, Andrejiová A (2015) Impact of biofortification, variety and cutting on chosen qualitative characteristic of basil (Ocimum basilicum L.). Acta Fytotech Zootech 18:71-75. https://doi.org/10.15414/afz.2015.18.03.71-75

Bastani S, Hajiboland R, Khatamian M, Saket-Oskoui M (2018) Nano iron $(\mathrm{Fe})$ complex is an effective source of fe for tobacco plants grown under low Fe supply. J Soil Sci Plant Nutr 18:524-541. https://doi.org/10.4067/S0718-95162018005001602

Bouis HE, Saltzman A (2017) Improving nutrition through biofortification: a review of evidence from HarvestPlus, 2003 through 2016. Glob Food Sec 12:49-58. https://doi.org/10.1016/j.gfs. 2017.01.009

Cecílio Filho AB, Mendoza Cortez JW, de Sordi D, Urrestarazu M (2015) Common chicory performance as influenced by iron concentration in the nutrient solution. J Plant Nutr 38:14891494. https://doi.org/10.1080/01904167.2014.983609

Deng X, Liu K, Li M, Zhang W, Zhao X, Zhao Z, Liu X (2017) Difference of selenium uptake and distribution in the plant and selenium form in the grains of rice with foliar spray of selenite or selenate at different stages. F Crop Res 211:165-171. https://doi.org/10.1016/j.fcr.2017.06.008

Deshpande P, Dapkekar A, Oak MD, Paknikar KM, Rajwade JM (2017) Zinc complexed chitosan/TPP nanoparticles: a promising micronutrient nanocarrier suited for foliar application. Carbohydr Polym 165:394-401. https://doi.org/10.1016/j.carbp ol.2017.02.061

Djanaguiraman M, Belliraj N, Bossmann SH, Prasad PVV (2018) High-temperature stress alleviation by selenium nanoparticle treatment in grain sorghum. ACS Omega 3:2479-2491. https:// doi.org/10.1021/acsomega.7b01934

Du W, Yang J, Peng Q, Liang X, Mao H (2019) Comparison study of zinc nanoparticles and zinc sulphate on wheat growth: from toxicity and zinc biofortification. Chemosphere 227:109-116. https://doi.org/10.1016/j.chemosphere.2019.03.168

Ebrahimi N, Stoddard FL, Hartikainen H, Seppänen MM (2019) Plant species and growing season weather influence the efficiency of selenium biofortification. Nutr Cycl Agroecosystems 114:111-124. https://doi.org/10.1007/s10705-019-09994-z

Edelstein M, Berstein D, Shenker M, Azaizeh H, Ben-Hur M (2016) Effects of selenium on growth parameters of tomato and basil under fertigation management. HortScience 51:1050-1056. https://doi.org/10.21273/HORTSCI.51.8.1050

Elanchezhian R, Kumar D, Ramesh K, Biswas AK, Guhey A, Patra AK (2017) Morpho-physiological and biochemical response of maize (Zea mays L.) plants fertilized with nano-iron $\left(\mathrm{Fe}_{3} \mathrm{O}_{4}\right)$ micronutrient. J Plant Nutr 40:1969-1977. https://doi.org/10. 1080/01904167.2016.1270320

El-ramady H, Abdalla N, Elbasiouny H, Elbehiry F, Elsakhawy T (2021) Nano-biofortification of different crops to immune against COVID-19: A review. Ecotoxicol Environ Saf 222:12500. https://doi.org/10.1016/j.ecoenv.2021.112500

Elsheery NI, Sunoj VSJ, Wen Y, Zhu JJ, Muralidharan G, Cao KF (2020) Foliar application of nanoparticles mitigates the chilling effect on photosynthesis and photoprotection in sugarcane. Plant Physiol Biochem 149:50-60. https://doi.org/10.1016/j. plaphy.2020.01.035 
Farooq M, Ullah A, Usman M, Siddique KHM (2020) Application of zinc and biochar help to mitigate cadmium stress in bread wheat raised from seeds with high intrinsic zinc. Chemosphere 260:127652. https://doi.org/10.1016/j.chemosphere. 2020.127652

Galinha C, Sánchez-Martínez M, Pacheco AMG, do Freitas MC, Coutinho J, Maçãs B, Almeida AS, Pérez-Corona MT, Madrid Y, Wolterbeek HT (2014) Characterization of selenium-enriched wheat by agronomic biofortification. J Food Sci Technol 52:4236-4245. https://doi.org/10.1007/s13197-014-1503-7

Garg M, Sharma N, Sharma S, Kapoor P, Kumar A, Chunduri V, Arora $P$ (2018) Biofortified crops generated by breeding, agronomy, and transgenic approaches are improving lives of millions of people around the. World Front Nutr 5:12. https://doi.org/10.3389/ fnut. 2018.00012

Giordano M, El-Nakhel C, Pannico A, Kyriacou MC, Stazi SR, De Pascale S, Rouphael Y (2019) Iron biofortification of red and green pigmented lettuce in closed soilless cultivation impacts crop performance and modulates mineral and bioactive composition. Agronomy 9:290. https://doi.org/10.3390/agronomy9060290

Di Gioia F, Petropoulos SA, Ozores-Hampton M, Morgan K, Rosskopf EN (2019) Zinc and iron agronomic biofortification of Brassicaceae microgreens. Agronomy 9:677. https://doi.org/10.3390/ agronomy9110677

Golubkina N, Gomez LD, Kekina H et al (2020) Joint selenium-iodine supply and arbuscular mycorrhizal fungi inoculation affect yield and quality of chickpea seeds and residual biomass. Plants 9:804. https://doi.org/10.3390/plants9070804

Golubkina N, Zamana S, Seredin T, Poluboyarinov P, Sokolov S, Baranova H, Krivenkov L, Pietrantonio L, Caruso G (2019) Effect of selenium biofortification and beneficial microorganism inoculation on yield, quality and antioxidant properties of shallot bulbs. Plants 8:102. https://doi.org/10.3390/plants8040102

Gomez-Coronado F, Poblaciones MJ, Almeida AS, Cakmak I (2016) Zinc $(\mathrm{Zn})$ concentration of bread wheat grown under Mediterranean conditions as affected by genotype and soil/foliar $\mathrm{Zn}$ application. Plant Soil 401:331-346. https://doi.org/10.1007/ s11104-015-2758-0

Gonzalez D, Almendros P, Obrador A, Alvarez JM (2019) Zinc application in conjunction with urea as a fertilization strategy for improving both nitrogen use efficiency and the zinc biofortification of barley. J Sci Food Agric 99:4445-4451. https://doi.org/ 10.1002/jsfa.9681

Gudkov SV, Shafeev GA, Glinushkin AP et al (2020) Production and use of selenium nanoparticles as fertilizers. ACS Omega 5:17767-17774. https://doi.org/10.1021/acsomega.0c02448

Haider MU, Farooq M, Nawaz A, Hussain M (2018a) Foliage applied zinc ensures better growth, yield and grain biofortification of mungbean. Int J Agric Biol 20:2817-2822. https://doi.org/10. 17957/IJAB/15.0840

Haider MU, Hussain M, Farooq M, Nawaz A (2018b) Soil application of zinc improves the growth, yield and grain zinc biofortification of mungbean. Soil Environ 37:123-128. https://doi.org/10. 25252/SE/18/71610

Hawrylak-Nowak B, Matraszek R, Pogorzelec M (2015) The dual effects of two inorganic selenium forms on the growth, selected physiological parameters and macronutrients accumulation in cucumber plants. Acta Physiol Plant 37:41. https://doi.org/10. 1007/s11738-015-1788-9

Huang C, Qin N, Sun L, Yu M, Hu W, Qi Z (2018) Selenium improves physiological parameters and alleviates oxidative stress in strawberry seedlings under low-temperature stress. Int J Mol Sci 19:1913. https://doi.org/10.3390/ijms19071913
Huang S, Wang P, Yamaji N, Ma JF (2020) Plant nutrition for human nutrition: hints from rice research and future perspectives. Mol Plant 13:825-835. https://doi.org/10.1016/j.molp.2020.05.007

Hussain A, Ali S, Rizwan M, Rehman MZ, ur, Qayyum MF, Wang H, Rinklebe J, (2019) Responses of wheat (Triticum aestivum) plants grown in a Cd contaminated soil to the application of iron oxide nanoparticles. Ecotoxicol Environ Saf 173:156-164. https://doi.org/10.1016/j.ecoenv.2019.01.118

Hussein HAA, Darwesh OM, Mekki BB, El-Hallouty SM (2019) Evaluation of cytotoxicity, biochemical profile and yield components of groundnut plants treated with nano-selenium. Biotechnol Reports 24:e00377. https://doi.org/10.1016/j.btre.2019.e00377

Izydorczyk G, Ligas B, Mikula K, Witek-Krowiak A, Moustakas K, Chojnacka K (2021) Biofortification of edible plants with selenium and iodine - a systematic literature review. Sci Total Environ 754:141983. https://doi.org/10.1016/j.scitotenv.2020.141983

Jalal A, Shah S, Filho CMT, M, Khan A, Shah T, Ilyas M, Leonel Rosa PA, (2020) Agro-biofortification of zinc and iron in wheat grains. Gesunde Pflanz 72:227-236. https://doi.org/10.1007/ s10343-020-00505-7

Jiang P, Liu J, Chen M, Yu G, You S, Li J (2020) Exogenous selenium improves the physiological resistance of cucumber to cadmium stress. Toxicol Environ Chem 102:455-472. https://doi.org/10. 1080/02772248.2020.1798449

Jones GD, Droz B, Greve P, Gottschalk P, Poffet D, McGrath SP, Seneviratne SI, Smith P, Winkel LHE (2017) Selenium deficiency risk predicted to increase under future climate change. Proc Natl Acad Sci USA 114:2848-2853. https://doi.org/10. 1073/pnas.1611576114

Karimi R, Ghabooli M, Rahimi J, Amerian M (2020) Effects of foliar selenium application on some physiological and phytochemical parameters of Vitis vinifera L. cv. Sultana under salt stress. J Plant Nutr 182:2226-2242. https://doi.org/10.1080/01904167. 2020.1766072

Lara TS, de Lessa JH, L, de Souza KRD, Corguinha APB, Martins FAD, Lopes G, Guilherme LRG, (2019) Selenium biofortification of wheat grain via foliar application and its effect on plant metabolism. J Food Compos Anal 81:10-18. https://doi.org/10. 1016/j.jfca.2019.05.002

Leija-Martínez P, Benavides-Mendoza A, Cabrera-De La Fuente M, Robledo-Olivo A, Ortega-Ortíz H, Sandoval-Rangel A, González-Morales S (2018) Lettuce biofortification with selenium in chitosan-polyacrylic acid complexes. Agronomy 8:275. https://doi.org/10.3390/agronomy8120275

Li D, Zhou C, Zhang J, An Q, Wu Y, Li JQ, Pan C (2020a) Nanoselenium foliar applications enhance the nutrient quality of pepper by activating the capsaicinoid synthetic pathway. J Agric Food Chem 68:9888-9895. https://doi.org/10.1021/acs.jafc.0c03044

Li J, Hu J, Ma C, Wang Y, Wu C, Huang J, Xing B (2016) Uptake, translocation and physiological effects of magnetic iron oxide $\left(\gamma-\mathrm{Fe}_{2} \mathrm{O}_{3}\right)$ nanoparticles in corn (Zea mays L.). Chemosphere 159:326-334. https://doi.org/10.1016/j.chemosphere.2016.05. 083

Li X, Wu Y, Li B, Yang Y, Yang Y (2018) Selenium accumulation characteristics and biofortification potentiality in turnip (Brassica rapa var. rapa) supplied with selenite or selenate. Front Plant Sci 8:2207. https://doi.org/10.3389/fpls.2017.02207

Li Y, Zhu N, Liang X, Zheng L, Zhang C, Li YF, Zhang Z, Gao Y, Zhao J (2020b) A comparative study on the accumulation, translocation and transformation of selenite, selenate, and SeNPs in a hydroponic-plant system. Ecotoxicol Environ Saf 189:109955. https://doi.org/10.1016/j.ecoenv.2019.109955

Liu D, Liu Y, Zhang W, Chen X, Zou C (2017) Agronomic approach of zinc biofortification can increase zinc bioavailability in wheat flour and thereby reduce zinc deficiency in humans. Nutrients 9:465. https://doi.org/10.3390/nu9050465 
Liu DY, Liu YM, Zhang W, Chen XP, Zou CQ (2019) Zinc uptake, translocation, and remobilization in winter wheat as affected by soil application of $\mathrm{Zn}$ fertilizer. Front Plant Sci 10:426. https:// doi.org/10.3389/fpls.2019.00426

Lingyun Y, Jian W, Chenggang W, Shan L, Shidong Z (2016) Effect of zinc enrichment on growth and nutritional quality in pea sprouts. J Food Nutr Res 4:100-107

Longchamp M, Castrec-Rouelle M, Biron P, Bariac T (2015) Variations in the accumulation, localization and rate of metabolization of selenium in mature Zea mays plants supplied with selenite or selenate. Food Chem 182:128-135. https://doi.org/10.1016/j. foodchem.2015.02.137

de Mangueze AV, J, Pessoa MFG, Silva MJ, et al (2018) Simultaneous zinc and selenium biofortification in rice. Accumulation, localization and implications on the overall mineral content of the flour. J Cereal Sci 82:34-41. https://doi.org/10.1016/j.jcs.2018. 05.005

Manojlović MS, Lončarić Z, Cabilovski RR, Popović B, Karalić K, Ivezić V, Ademi A, Singh BR (2019) Biofortification of wheat cultivars with selenium. Acta Agric Scand Sect B Soil Plant Sci 69:715-724. https://doi.org/10.1080/09064710.2019.1645204

Márquez-Quiroz C, De-La-cruz-Lázaro E, Osorio-Osorio R, SánchezChávez E (2015) Biofortification of cowpea beans with iron: iron's influence on mineral content and yield. J Soil Sci Plant Nutr 15:839-847. https://doi.org/10.4067/S0718-9516201500 5000058

Mezeyova I, Hegedusova A (2016) Phytomass and content of essential oils in Ocimum basilicum after foliar treatment with selenium. Agric Food 4:19-27

Montoya M, Vallejo A, Recio J, Guardia G, Alvarez JM (2020) Zinc nitrogen interaction effect on wheat biofortification and nutrient use efficiency. J Plant Nutr Soil Sci 183:169-179. https://doi.org/ 10.1002/jpln.201900339

Morales-Espinoza MC, Cadenas-pliego G, Marissa P, Delia A, Cabrera M, Fuente D (2019) Se nanoparticles induce changes in the growth, antioxidant responses, and fruit quality of tomato developed under $\mathrm{NaCl}$ stress. Molecules 24:3030. https://doi.org/10. 3390/molecules24173030

Mumtaz MZ, Ahmad M, Jamil M, Asad SA, Hafeez F (2018) Bacillus strains as potential alternate for zinc biofortification of maize grains. Int J Agric Biol 20:1779-1786

Nawaz F, Ashraf MY, Ahmad R, Waraich EA, Shabbir RN, Hussain RA (2017) Selenium supply methods and time of application influence spring wheat (Triticum aestivum L.) yield under water deficit conditions. J Agric Sci 155:643-656. https://doi.org/10. 1017/S0021859616000836

Newman RG, Moon Y, Sams CE, Tou JC, Waterland NL (2021) Biofortification of sodium selenate improves dietary mineral contents and antioxidant capacity of culinary herb microgreens. Front Plant Sci 12:716437. https://doi.org/10.3389/fpls.2021.716437

Niu H, Zhan K, Xu W, Peng C, Hou C, Li Y, Hou R, Wan X, Cai H (2020) Selenium treatment modulates fluoride distribution and mitigates fluoride stress in tea plant (Camellia sinensis (L.) O. Kuntze). Environ Pollut 267:115603. https://doi.org/10.1016/j. envpol.2020.115603

Niyigaba E, Twizerimana A, Mugenzi I, Ngnadong WA, Ye YP, Wu BM, Hai JB (2019) Winter wheat grain quality, zinc and iron concentration affected by a combined foliar spray of zinc and iron fertilizers. Agronomy 9:250. https://doi.org/10.3390/agron omy 9050250

Noreen S, Sultan M, Akhter MS, Shah KH, Ummara U, Manzoor H, Ulfat M, Alyemeni MN, Ahmad P (2020) Foliar fertigation of ascorbic acid and zinc improves growth, antioxidant enzyme activity and harvest index in barley (Hordeum vulgare L.) grown under salt stress. Plant Physiol Biochem 158:244-254. https:// doi.org/10.1016/j.plaphy.2020.11.007

Padash A, Shahabivand S, Behtash F, Aghaee A (2016) A practicable method for zinc enrichment in lettuce leaves by the endophyte fungus Piriformospora indica under increasing zinc supply. Sci Hortic 213:367-372. https://doi.org/10.1016/j.scienta.2016.10. 040

Pal V, Singh G, Dhaliwal SS (2019) Agronomic biofortification of chickpea with zinc and iron through application of zinc and urea. Commun Soil Sci Plant Anal 50:1864-1877. https://doi.org/10. 1080/00103624.2019.1648490

Park S, Grusak MA, Oh M (2015) Concentrations of minerals and phenolic compounds in three edible sprout species treated with iron-chelates during imbibition concentrations of minerals. Hort Environ Biotechnol 55:471-478. https://doi.org/10.1007/ s13580-014-0075-9

Patel P, Trivedi G, Saraf M (2018) Iron biofortification in mungbean using siderophore producing plant growth promoting bacteria. Environ Sustain 1:357-365. https://doi.org/10.1007/ s42398-018-00031-3

Persson DP, de Bang TC, Pedas PR, Kutman UB, Cakmak I, Andersen B, Finnie C, Schjoerring JK, Husted S (2016) Molecular speciation and tissue compartmentation of zinc in durum wheat grains with contrasting nutritional status. New Phytol 211:1255-1265. https://doi.org/10.1111/nph.13989

Praharaj S, Skalicky M, Maitra S, Bhadra P, Shankar T, Brestic M, Hejnak V, Vachova P, Hossain A (2021) Zinc biofortification in food crops could alleviate the zinc malnutrition in human health. Molecules 26:3509. https://doi.org/10.3390/molecules26123509

Prom-u-thai C, Rashid A, Ram H et al (2020) Simultaneous biofortification of rice with zinc, iodine, iron and selenium through foliar treatment of a micronutrient cocktail in five countries. Front Plant Sci 11:589835. https://doi.org/10.3389/fpls.2020.589835

Puccinelli M, Pezzarossa B, Pintimalli L, Malorgio F (2021a) Selenium biofortification of three wild species, Rumex cetosa L., Plantago coronopus L., and Portulaca oleracea L., grown as microgreens. Agronomy 11:1155. https://doi.org/10.3390/agronomy11061155

Puccinelli M, Landi M, Maggini R, Pardossi A, Incrocci L (2021b) Iodine biofortification of sweet basil and lettuce grown in two hydroponic systems. Sci Hortic 276:109783. https://doi.org/10. 1016/j.scienta.2020.109783

Puccinelli M, Pezzarossa B, Rosellini I, Malorgio F (2020) Selenium enrichment enhances the quality and shelf life of basil leaves. Plants 9:801. https://doi.org/10.3390/plants9060801

Puccinelli M, Malorgio F, Maggini R, Rosellini I, Pezzarossa B (2019a) Biofortification of Ocimum basilicum L. plants with selenium. Acta Hortic 1242:663-670. https://doi.org/10.17660/ActaHortic. 2019.1242.98

Puccinelli M, Malorgio F, Rosellini I, Pezzarossa B (2019b) Production of selenium-biofortified microgreens from selenium-enriched seeds of basil. J Sci Food Agric 99:5601-5605. https://doi.org/ $10.1002 /$ jsfa.9826

Puccinelli M, Malorgio F, Rosellini I, Pezzarossa B (2017) Uptake and partitioning of selenium in basil (Ocimum basilicum L.) plants grown in hydroponics. Sci Hortic 225:271-276. https://doi.org/ 10.1016/j.scienta.2017.07.014

Ramzan Y, Hafeez MB, Khan S, Nadeem M, Saleem-ur-Rahman BS, Ahmad J (2020) Biofortification with zinc and iron improves the grain quality and yield of wheat crop. Int J Plant Prod 14:501510. https://doi.org/10.1007/s42106-020-00100-w

Ramzani PMA, Khalid M, Naveed M, Ahmad R, Shahid M (2016) Iron biofortification of wheat grains through integrated use of organic and chemical fertilizers in $\mathrm{pH}$ affected calcareous soil. Plant Physiol Biochem 104:284-293. https://doi.org/10.1016/j. plaphy.2016.04.053 
Rivera-Martin A, Broadley MR, Poblaciones MJ (2020) Soil and foliar zinc biofortification of broccolini: effects on plant growth and mineral accumulation. Crop Pasture Sci 71:484-490. https://doi. org/10.1071/CP19474

Rizwan M, Ali S, Ali B, Adrees M, Arshad M, Hussain A, Zia ur Rehman M, Waris AA, (2019) Zinc and iron oxide nanoparticles improved the plant growth and reduced the oxidative stress and cadmium concentration in wheat. Chemosphere 214:269-277. https://doi.org/10.1016/j.chemosphere.2018.09.120

Ros GH, van Rotterdam AMD, Bussink DW, Bindraban PS (2016) Selenium fertilization strategies for bio-fortification of food: an agro-ecosystem approach. Plant Soil 404:99-112. https://doi.org/ 10.1007/s11104-016-2830-4

Sabatino L, Ntatsi G, Iapichino G, D'anna F, De Pasqual C (2019) Effect of selenium enrichment and type of application on yield, functional quality and mineral composition of curly endive grown in a hydroponic system. Agronomy 9:207. https://doi. org/10.3390/agronomy9040207

Sago Y, Watanabe N, Minami Y (2018) Zinc biofortification of hydroponic baby leaf lettuce grown under artificial lighting with elevated wind speed and root zone temperature. J Agric Meteorol 74:173-177. https://doi.org/10.2480/agrmet.D-17-00048

Sahab S, Suhani I, Srivastava V, Chauhan PS, Singh RP, Prasad V (2021) Potential risk assessment of soil salinity to agroecosystem sustainability: Current status and management strategies. Sci Total Environ 764:144164. https://doi.org/10.1016/j.scito tenv.2020.144164

Sambo P, Nicoletto C, Giro A et al (2019) Hydroponic Solutions for soilless production systems: Issues and opportunities in a smart agriculture perspective. Front Plant Sci 10:923. https://doi.org/ 10.3389/fpls.2019.00923

Schiavon M, Berto C, Malagoli M, Trentin A, Sambo P, Dall'Acqua S, Pilon-Smits EAH, (2016) Selenium biofortification in radish enhances nutritional quality via accumulation of methyl-selenocysteine and promotion of transcripts and metabolites related to glucosinolates, phenolics amino acids. Front Plant Sci 7:1371. https://doi.org/10.3389/fpls.2016.01371

Shah WH, Rasool A, Tahir I, Rehman RU (2020) Exogenously applied selenium (Se) mitigates the impact of salt stress in Setaria italica L. and Panicum miliaceum L. Nucl 63:327-339. https://doi.org/ 10.1007/s13237-020-00326-z

Sharma S, Malhotra H, Borah P, Meena MK, Bindraban P, Chandra S, Pande V, Pandey R (2019) Foliar application of organic and inorganic iron formulation induces differential detoxification response to improve growth and biofortification in soybean. Plant Physiol Reports 24:119-128. https://doi.org/10.1007/ s40502-018-0412-6

Sheikhalipour M, Esmaielpour B, Behnamian M, Gohari G, Giglou MT, Vachova P, Rastogi A, Brestic M, Skalicky M (2021) Chitosan-selenium nanoparticle (Cs-Se NP) foliar spray alleviates salt stress in bitter melon. Nanomaterials 11:684. https://doi.org/ 10.3390/nano11030684

Siddiqui SA, Blinov AV, Serov AV et al (2021) Effect of selenium nanoparticles on germination of Hordéum vulgáre barley seeds. Coatings 11:862. https://doi.org/10.3390/coatings 11070862

da Silva DF, Cipriano PE, de Souza RR, Siueia M, Faquin V, de Souza Silva ML, Guilherme LRG (2020) Biofortification with selenium and implications in the absorption of macronutrients in Raphanus sativus L. J Food Compos Anal 86:103382. https://doi.org/10. 1016/j.jfca.2019.103382

Skrypnik L, Novikova A, Tokupova E (2019) Improvement of phenolic compounds, essential oil content and antioxidant properties of sweet basil (Ocimum basilicum L.) depending on type and concentration of selenium application. Plants 8:458. https://doi.org/ $10.3390 /$ plants 8110458
Smažíková P, Praus L, Száková J, Tremlová J, Hanč A, Tlustoš P (2019) Effects of organic matter-rich amendments on selenium mobility in soils. Pedosphere 29:740-751. https://doi.org/10. 1016/S1002-0160(17)60444-2

Smoleń S, Kowalska I, Kováčik P, Halka M, Sady W (2019) Biofortification of six varieties of lettuce (Lactuca sativa $\mathrm{L}$.) with iodine and selenium in combination with the application of salicylic acid. Front Plant Sci 10:143. https://doi.org/10.3389/fpls.2019. 00143

Subbaiah LV, Prasad TNVKV, Krishna TG, Sudhakar P, Reddy BR, Pradeep T (2016) Novel effects of nanoparticulate delivery of zinc on growth, productivity, and zinc biofortification in maize (Zea mays L.). J Agric Food Chem 64:3778-3788. https://doi. org/10.1021/acs.jafc.6b00838

Tarafder C, Daizy M, Alam MM, Ali MR, Islam MJ, Islam R, Ahommed MS, Aly Saad Aly M, Khan MZH (2020) Formulation of a hybrid nanofertilizer for slow and sustainable release of micronutrients. ACS Omega 5:23960-23966. https://doi.org/10. 1021/acsomega.0c03233

Tian M, Xu X, Liu Y, Xie L, Pan S (2016) Effect of Se treatment on glucosinolate metabolism and health-promoting compounds in the broccoli sprouts of three cultivars. Food Chem 190:374-380. https://doi.org/10.1016/j.foodchem.2015.05.098

Tran BTT, Cavagnaro TR, Watts-Williams SJ (2019) Arbuscular mycorrhizal fungal inoculation and soil zinc fertilisation affect the productivity and the bioavailability of zinc and iron in durum wheat. Mycorrhiza 29:445-457. https://doi.org/10.1007/ s00572-019-00911-4

Triticum W, Abaid-ullah M, Hassan MN, Jamil M, Brader G, Kausar M (2015) Plant growth promoting rhizobacteria : an alternate way to improve yield and plant growth promoting rhizobacteria : an alternate way to improve yield and quality of wheat (Triticum aestivum). Int J Agric Biol 7:51-60

Turner ER, Luo Y, Buchanan RL (2020) Microgreen nutrition, food safety, and shelf life: a review. J Food Sci 85:870-882

Vicas SI, Cavalu S, Laslo V, Tocai M, Costea TO, Moldovan L (2019) Growth, photosynthetic pigments, phenolic, glucosinolates content and antioxidant capacity of broccoli sprouts in response to nanoselenium particles supply. Not Bot Horti Agrobot ClujNapoca 47:821-828. https://doi.org/10.15835/nbha47311490

Wang K, Wang Y, Li K, Wan Y, Wang Q, Zhuang Z, Guo Y, Li H (2020a) Uptake, translocation and biotransformation of selenium nanoparticles in rice seedlings (Oryza sativa L.). J Nanobiotechnology 18:103. https://doi.org/10.1186/s12951-020-00659-6

Wang M, Ali F, Wang M, Dinh QT, Zhou F, Bañuelos GS, Liang D (2020b) Understanding boosting selenium accumulation in wheat (Triticum aestivum L.) following foliar selenium application at different stages, forms, and doses. Environ Sci Pollut Res 27:717-728. https://doi.org/10.1007/s11356-019-06914-0

Yahyaoui A, Djebar MR, Khene L, Bouarroudj T, Kahli H, Bourayou C (2017) Assessment of exposure wheat Triticum aestivum L. To zinc oxide nanoparticles ( $\mathrm{ZnO})$ : Evaluation of oxidative damage. Studia Univ VG, SSV 27:271-280

Yasin M, El-Mehdawi AF, Anwar A, Pilon-Smits EAH, Faisal M (2015a) Microbial-enhanced selenium and iron biofortification of wheat (Triticum aestivum L.) - Applications in Phytoremediation and Biofortification. Int J Phytoremediation 17:341-347. https://doi.org/10.1080/15226514.2014.922920

Yasin M, El-Mehdawi AF, Pilon-Smits EAH, Faisal M (2015b) Selenium-fortified wheat: potential of microbes for biofortification of selenium and other essential nutrients. Int J Phytoremediation 17:777-786. https://doi.org/10.1080/15226514.2014.987372

Yin H, Qi Z, Li M, Ahammed GJ, Chu X, Zhou J (2019) Selenium forms and methods of application differentially modulate plant growth, photosynthesis, stress tolerance, selenium content and 
speciation in Oryza sativa L. Ecotoxicol Environ Saf 169:911917. https://doi.org/10.1016/j.ecoenv.2018.11.080

Zhang R, Zhang H, Tu C, Hu X, Li L, Luo Y, Christie P (2015) Phytotoxicity of $\mathrm{ZnO}$ nanoparticles and the released $\mathrm{Zn}(\mathrm{II})$ ion to corn (Zea mays L.) and cucumber (Cucumis sativus L.) during germination. Environ Sci Pollut Res 22:11109-11117. https:// doi.org/10.1007/s11356-015-4325-x

Publisher's Note Springer Nature remains neutral with regard to jurisdictional claims in published maps and institutional affiliations. 